Supporting Information for

2

\title{
Microbial turnover of glyphosate to biomass: utilization as nutrient source, formation of AMPA and biogenic NER in an OECD 308 test
}

Andreas Libonati Brock ${ }^{1}$, Arno Rein ${ }^{2}$, Fabio Polesel ${ }^{1}$, Karolina M. Nowak ${ }^{3}$, Matthias Kästner ${ }^{3^{*}}$, Stefan Trapp ${ }^{1}$

${ }^{1}$ Department of Environmental Engineering, Technical University of Denmark, Bygningstorvet 115, 2800 Kgs. Lyngby, Denmark

${ }^{2}$ Chair of Hydrogeology, Technical University of Munich, Arcisstrasse 21, Munich 80333, Germany

${ }^{3}$ Department of Environmental Biotechnology, Helmholtz-Centre for Environmental Research-UFZ Permoserstrasse 15, 04318 Leipzig, Germany

\section{${ }^{*}$ Corresponding author:}

Matthias Kästner, e-mail: matthias.kaestner@ufz.de, phone: +49 341/235-1235; Fax: +49 341/235451235

The supporting information contains information regarding:

S1. Data for calculating the microbial growth yields

S2. Half-reactions

S3. Amino acids hydrolyzed from proteins as a measure for bioNER

S4. Model implementation

S5. DREAM parameter optimization and uncertainty analysis

S6. Testing of alternative hypotheses

S7. Carbon and nitrogen mass balance

S8. Calculation of biomass and $\mathrm{CO}_{2}$ formation with the modified MTB carbon balance 
Table S1: Chemical structure, chemical mass, carbon-hydrogen bonds, microbial yield on ATP ( $\left.Y_{\text {ATP }}\right)$, Gibbs free energy of formation at $\mathrm{pH}=7$, activity $=0.1 \mathrm{mmol} \mathrm{L}^{-1}$, ionic strength of $0.1 \mathrm{~mol}$ $\mathrm{L}^{-1}\left(\Delta G_{f}^{m \prime}\right)$ for glyphosate, its metabolites and reaction educts and products.

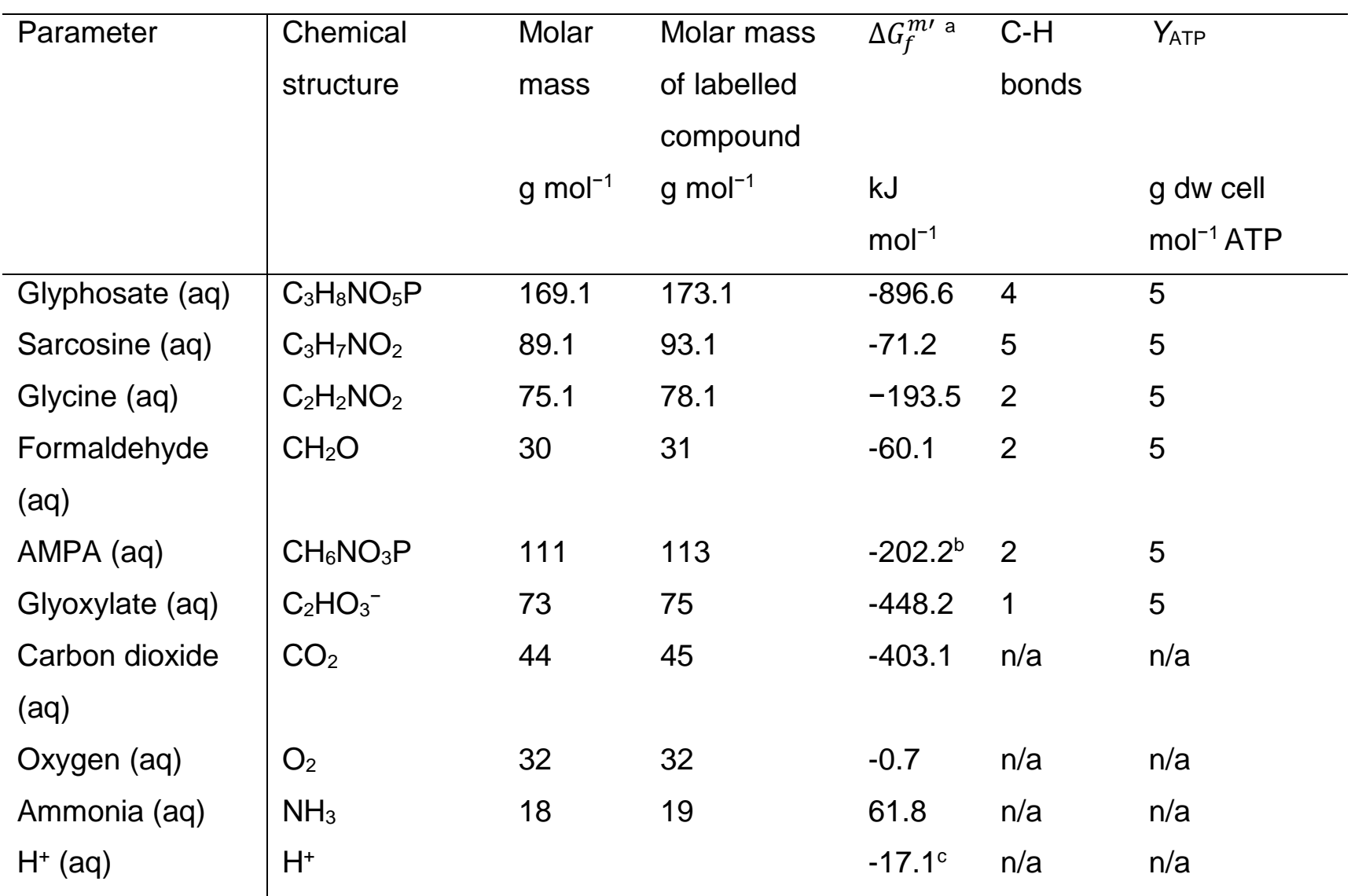

a The Gibbs free energy of formation was calculated using eQuilibrator, http://equilibrator.weizmann.ac.il/,1 except for ${ }^{b}$ AMPA, which was taken from MetaCyc ${ }^{2}$ and computed based on the method for thermodynamic calculations of biochemical reactions proposed by Alberty ${ }^{3}$, cin which $\mathrm{H}^{+}$is defined as having $0 \mathrm{~kJ} \mathrm{~mol}^{-1}$ Gibbs free energy. 


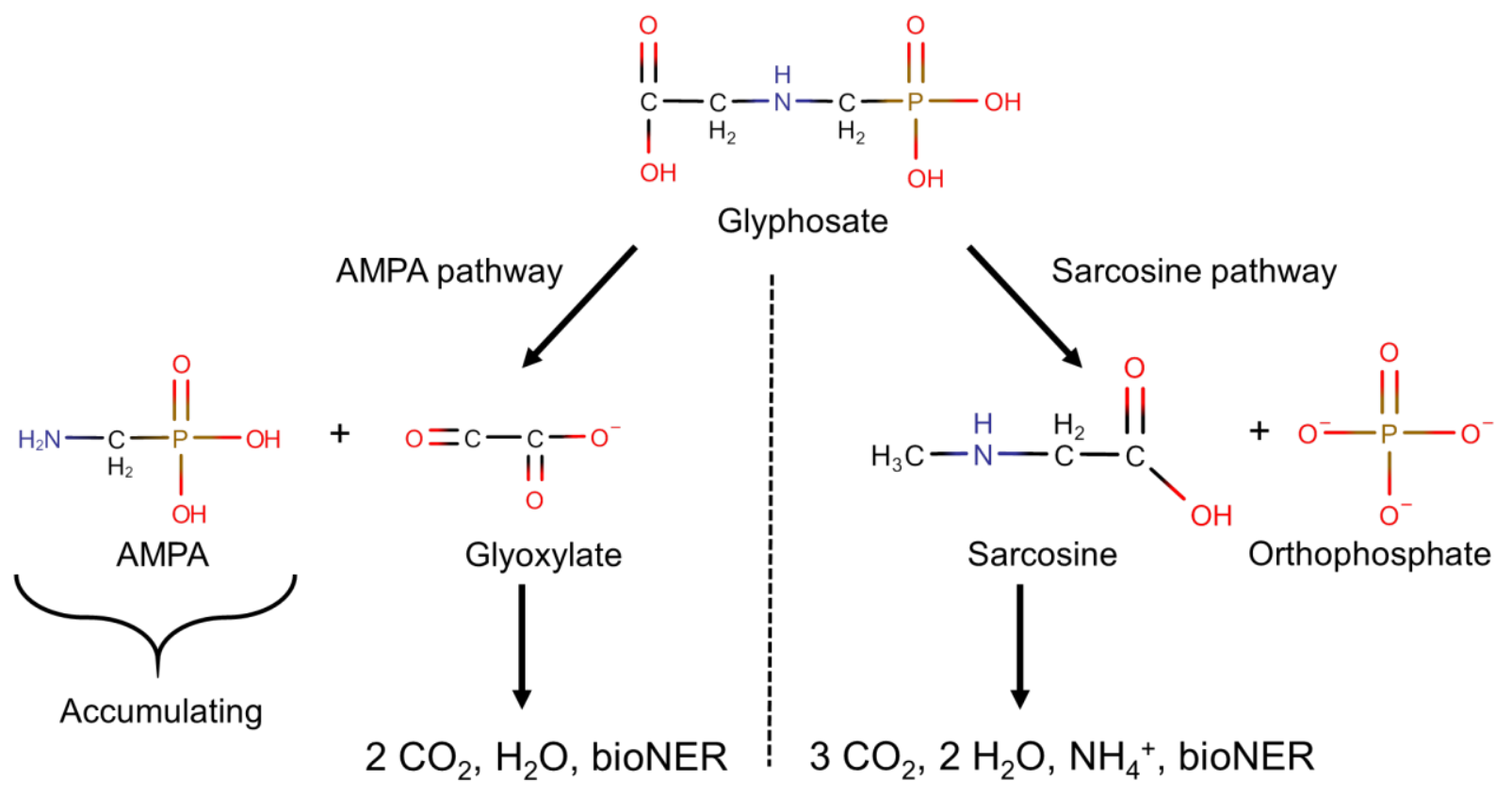

Figure S1. Proposed microbial degradation of glyphosate through the sarcosine and AMPA pathways. ${ }^{4-6}$ AMPA is readily detected and can, under certain conditions, be considered an accumulating metabolite.

\section{S2.1 Sarcosine pathway}

First, Glyphosate is transformed into equimolar amounts of sarcosine $\left(\mathrm{C}_{3} \mathrm{H}_{7} \mathrm{NO}_{2}\right)$ and phosphate/phosphoric acid through cleavage of the carbon-phosphorous bond:

$$
\begin{gathered}
\mathrm{C}_{3} \mathrm{H}_{8} \mathrm{NO}_{5} \mathrm{P}+\mathrm{H}_{2} \mathrm{O} \leftrightharpoons \mathrm{C}_{3} \mathrm{H}_{7} \mathrm{NO}_{2}+\mathrm{H}_{3} \mathrm{PO}_{4} \\
\Delta G_{d}^{m \prime}=-90 \mathrm{~kJ} \mathrm{~mol}^{-1}
\end{gathered}
$$

$\mathrm{P}$ is oxidized from phosphonate (+III) to phosphate (+V) and the two electrons are used to reduce the $\mathrm{C}$ in sarcosine. Sarcosine is further transformed into equimolar quantities of glycine $\left(\mathrm{C}_{2} \mathrm{H}_{5} \mathrm{NO}_{2}\right)$ and formaldehyde $\left(\mathrm{CH}_{2} \mathrm{O}\right)$ :

$$
\begin{gathered}
\mathrm{C}_{3} \mathrm{H}_{7} \mathrm{NO}_{2}+\mathrm{H}_{2} \mathrm{O} \leftrightharpoons \mathrm{C}_{2} \mathrm{H}_{5} \mathrm{NO}_{2}+\mathrm{CH}_{2} \mathrm{O}+2 \mathrm{H}^{+}+2 e^{-} \\
\Delta G_{d}^{m \prime}=-24.8 \mathrm{~kJ} \mathrm{~mol}^{-1}
\end{gathered}
$$

52

Glycine and formaldehyde are mineralized:

$$
\begin{gathered}
\mathrm{C}_{2} \mathrm{H}_{5} \mathrm{NO}_{2}+2 \mathrm{H}_{2} \mathrm{O} \leftrightharpoons 2 \mathrm{CO}_{2}+\mathrm{NH}_{4}^{+}+5 \mathrm{H}^{+}+6 e^{-} \\
\Delta G_{d}^{m \prime}=-235.7 \mathrm{~kJ} \mathrm{~mol}^{-1}
\end{gathered}
$$




$$
\begin{gathered}
\mathrm{CH}_{2} \mathrm{O}+\mathrm{H}_{2} \mathrm{O} \leftrightharpoons \mathrm{CO}_{2}++4 \mathrm{H}^{+}+4 e^{-} \\
\Delta G_{d}^{m \prime}=-185.4 \mathrm{~kJ} \mathrm{~mol}^{-1}
\end{gathered}
$$

54

55

The half-reaction describing the full oxidation of glyphosate to $\mathrm{CO}_{2}$ :

$$
\begin{gathered}
\mathrm{C}_{3} \mathrm{H}_{8} \mathrm{NO}_{5} \mathrm{P}+5 \mathrm{H}_{2} \mathrm{O} \leftrightharpoons 3 \mathrm{CO}_{2}+\mathrm{NH}_{4}^{+}+\mathrm{H}_{3} \mathrm{PO}_{4}+11 \mathrm{H}^{+}+12 e^{-} \\
\Delta G_{d}^{m \prime}=-536.2 \mathrm{~kJ} \mathrm{~mol}^{-1}
\end{gathered}
$$

56

57

58

59

60

61

AMPA and glyoxylate are further metabolized:

$$
\begin{gathered}
\mathrm{CH}_{6} \mathrm{NO}_{3} \mathrm{P}+3 \mathrm{H}_{2} \mathrm{O} \leftrightharpoons \mathrm{CO}_{2}+\mathrm{H}_{3} \mathrm{PO}_{4}+\mathrm{NH}_{3}+6 \mathrm{H}^{+}+6 e^{-} \\
\Delta G_{d}^{m \prime}=-739.6 \mathrm{~kJ} \mathrm{~mol}^{-1}
\end{gathered}
$$

62

$$
\begin{gathered}
\mathrm{C}_{2} \mathrm{HO}_{3}^{-}+\mathrm{H}_{2} \mathrm{O} \leftrightharpoons 2 \mathrm{CO}_{2}+3 \mathrm{H}^{+}+4 e^{-} \\
\Delta G_{d}^{m \prime}=-200.4 \mathrm{~kJ} \mathrm{~mol}^{-1}
\end{gathered}
$$

63

Assuming that AMPA is an accumulating metabolite, Equation S6 and S8 are added to yield the 64 reaction in which only glyoxylate is mineralized:

$$
\begin{gathered}
\mathrm{C}_{3} \mathrm{H}_{8} \mathrm{NO}_{5} \mathrm{P}+2 \mathrm{H}_{2} \mathrm{O} \leftrightharpoons \mathrm{CH}_{6} \mathrm{NO}_{3} \mathrm{P}+2 \mathrm{CO}_{2}+6 \mathrm{H}^{+}+6 e^{-} \\
\Delta G_{d}^{m \prime}=203.4 \mathrm{~kJ} \mathrm{~mol}^{-1}
\end{gathered}
$$

65

\section{S2.2 How to calculate the Gibbs free energy of a reaction}

67 To calculate the Gibbs free energy of a reaction, $\mathrm{O}_{2}$ is assumed to be the terminal electron 68 acceptor: 


$$
\begin{gathered}
\mathrm{O}_{2}+4 \mathrm{H}^{+}+4 e^{-} \leftrightharpoons 2 \mathrm{H}_{2} \mathrm{O} \\
\Delta G_{a}^{m \prime}=-314.5 \mathrm{~kJ} \mathrm{~mol}^{-1} \\
\Delta G_{a-e^{-}}^{m \prime}=-78.63 \mathrm{~kJ} \text { per mol } e^{-}
\end{gathered}
$$

69 Where the subscript a means acceptor and $\Delta G_{a-e^{-}}^{\prime m}$ is the Gibbs free energy of reaction per electron in the half-reaction. The Gibbs free energy of reaction is then

$$
\Delta G_{r}^{m \prime}=\Delta G_{d}^{m \prime}+n \times \Delta G_{a-e^{-}}^{m \prime}
$$

71 Where $n$ is the number of electrons released in the half-reaction of the electron donor.

For glyphosate oxidation to $\mathrm{CO}_{2}$, it is:

$$
\begin{gathered}
\Delta G_{r}^{m \prime}=-536.2 \mathrm{~kJ} \mathrm{~mol}^{-1}+12 e^{-} \times-78.63 \mathrm{~kJ} \mathrm{per} \mathrm{mol} e^{-} \\
=-1480 \mathrm{~kJ} \mathrm{~mol}^{-1}
\end{gathered}
$$

All results are summarized in Table 1.

\section{S3. Amino acids hydrolyzed from proteins as a measure for bioNER}

Microbial growth has been monitored by stable isotope incorporation into amino acids/proteins of living biomass ${ }^{4,7-11}$ To calculate the total label incorporation into other biomolecules than amino acids, a factor of 2 has usually been applied to calculate the biomass and bioNER resp., from measured amino acids. ${ }^{12}$ This factor is partly based on experiments ${ }^{7}$ in which $\sim 50 \%$ of the ${ }^{13} \mathrm{C}$ in the biomass was recovered in the amino acids, and partly based on the fact that approximately 45$55 \%$ of the bacterial dry weight is generally made up of proteins. ${ }^{13}$ However, since the incorporation of a label into amino acids is measured and not the biomass dry weight, the difference in the $\mathrm{C}$ and $\mathrm{N}$ contents of the specific amino acids together with their cellular abundance should be taken into account, when deriving this factor. The following factors $(f)$ for converting $\mathrm{C}$ and $\mathrm{N}$ amounts in amino acids to $\mathrm{C}$ and $\mathrm{N}$ amounts in bacterial cells were calculated using the frequency and the $\mathrm{C}$ and $\mathrm{N}$ content of 20 "biogenic" amino acids: ${ }^{14}$

To convert the measured incorporation of labeled carbon or nitrogen isotopes in amino acids to moles of carbon or nitrogen isotopes incorporated into bacterial biomass, the following steps must be undertaken 


$$
\begin{array}{r}
f_{\mathrm{AA}, \text { Cell }}^{\mathrm{N}}=\frac{\mathrm{mol}_{\mathrm{AA}}}{\mathrm{mol} \mathrm{N}_{\mathrm{AA}}} \times \frac{\mathrm{g}_{\mathrm{AA}}}{\mathrm{mol}_{\mathrm{AA}}} \times \frac{\mathrm{g} \mathrm{dw} \text { cell }}{\mathrm{g}_{\mathrm{AA}}} \times \frac{\mathrm{mol} \mathrm{dw} \text { cell }}{\mathrm{g} \mathrm{dw} \text { cell }} \times \frac{\mathrm{mol} \mathrm{N}_{\text {cell dw }}}{\mathrm{mol} \mathrm{dw} \mathrm{cell}} \\
f_{\mathrm{AA}, \text { Cell }}^{\mathrm{N}}=\frac{1}{1.35} \times 128.06 \times 2 \times \frac{1}{113} \times 1=1.7 \mathrm{~mol} \mathrm{~N}_{\text {cell dw }}\left(\mathrm{mol} \mathrm{N}_{\mathrm{AA}}\right)^{-1}
\end{array}
$$

$$
f_{\mathrm{AA}, \mathrm{C} e l l}^{\mathrm{C}}=\frac{1}{4.92} \times 128.06 \times 2 \times \frac{1}{113} \times 5=2.3 \mathrm{~mol} \mathrm{C}_{\mathrm{cell} \mathrm{dw}}\left(\mathrm{mol} \mathrm{C}_{\mathrm{AA}}\right)^{-1}
$$

By omitting the last term, one obtains the value needed to convert the measured value (in units mol $\mathrm{C}_{\mathrm{AA}}$ or mol $\mathrm{N}_{\mathrm{AA}}$ ) to moles of bacteria. Here ${ }^{15} \mathrm{~N}$ or ${ }^{13} \mathrm{C}$ incorporated into amino acids are used as proxies for the microbial biomass. Converting ${ }^{15} \mathrm{~N}$-total amino acids and ${ }^{13} \mathrm{C}$-total amino acids into mass of microorganisms should theoretically yield the same value. Importantly, these factors are only valid when there has been no substantial recycling of microbial necromass in the food web. ${ }^{16}$ The sugars and fatty acids in necromass are turned over fast, and the more stable amino acids accumulate on the long run. ${ }^{17,18}$ Hence, both factors will approach 1 for $t \rightarrow \infty .{ }^{16}$ from $f_{\mathrm{AA}, \mathrm{C} \text { ell }}^{\mathrm{C}}$ : 


$$
\begin{aligned}
& f_{\mathrm{AA}, \text { Cell }}^{\mathrm{N}}=f_{\mathrm{AA}, \text { Cell }}^{C} \times \frac{\mathrm{mol}_{\mathrm{AA}}}{\mathrm{mol} \mathrm{N}_{\mathrm{AA}}} \times \frac{\mathrm{mol} \mathrm{C}_{\mathrm{AA}}}{\mathrm{mol}_{\mathrm{AA}}} \times \frac{\mathrm{mol} \mathrm{N}_{\text {cell dw}}}{\mathrm{mol} \mathrm{C}_{\text {cell dw }}} \\
& f_{\mathrm{AA}, \text { Cell }}^{\mathrm{N}}=2.3 \times \frac{4.92}{1.35} \times \frac{1}{5}=1.7 \mathrm{~mol} \mathrm{~N}_{\text {cell dw }}\left(\mathrm{mol} \mathrm{N}_{\mathrm{AA}}\right)^{-1}
\end{aligned}
$$

116 The factors can be regarded as the likelihood of an isotope to end up in amino acids or other

117 biomolecules. The likelihood is proportional to the molar fraction of the element in the

118 biomolecules. This is only valid if no preferred metabolic pathway exists.

119 The 2.3 factor means that $1 / 2.3=43.5 \%$ of the cell $C$ is in amino acids, then the probability for a

$120{ }^{13} \mathrm{C}$ to end up in amino acids should be $43.5 \%$ and non-AA should be $100-43.5=56.5 \%$.

121 The growth yield can also be thought of as a probability measure, e.g. $Y=0.42 \mathrm{~mol} \mathrm{C} / \mathrm{mol} \mathrm{C}$

122 means that the ${ }^{13} \mathrm{C}$ has a $42 \%$ likelihood of ending up in the cell material and $58 \%$ of becoming

$123 \mathrm{CO}_{2}$. The overall likelihood of ending up as carbon in an amino acid is then $0.42 \times 0.435=18.3 \%$.

124 S3.1 Apparent conversion factors

125

126 "Apparent" conversion factors can be calculated by dividing the observed incorporation of the

127 isotope into total amino acids with the modeled incorporation. For $\mathrm{N}$, the observed factor was as

128 low as 0.16 (day 5 ) and increased to 0.97 by the end of the experiment (day 90). For $C$ it varied 129 from 0.33 to 1.90 .

130 
131 Table S2: Ubiquitous amino acids, their molar mass and average abundance in microbial proteins;

132 based upon these data, average molar mass of amino acid and average amount of $\mathrm{C}$ and $\mathrm{N}$ in

133 amino acids were calculated.

\begin{tabular}{|c|c|c|c|c|c|c|c|c|c|}
\hline $\begin{array}{l}\text { Amino acid } \\
(A A)\end{array}$ & $\begin{array}{c}\text { AA } \\
\text { molar } \\
\text { mass } \\
M_{A A, i} \\
{\left[\mathrm{~g} \mathrm{~mol}^{-1}\right]}\end{array}$ & $\begin{array}{c}\text { Average } \\
\text { AA abund. } \\
\text { (a) } \\
V_{A A, i} \\
{[\%]}\end{array}$ & $\begin{array}{c}\text { Fraction of } \\
\text { molar mass } \\
M_{A A, i} \\
\times v_{A A, i} \times 0.01 \\
{\left[\mathrm{~g} \mathrm{~mol}^{-1}\right]}\end{array}$ & $\begin{array}{c}\text { Moles of } \\
\text { C per } \\
\text { mole AA } \\
n_{C, A A, i} \\
{[\mathrm{~mol}(\mathrm{~mol}} \\
\left.A A)^{-1}\right]\end{array}$ & $\begin{array}{c}\text { Molar } \\
\text { mass of } \\
\text { C in AA } \\
M_{C, A A, i} \\
{\left[\mathrm{~g} \mathrm{~mol}^{-1}\right]}\end{array}$ & $\begin{array}{c}\text { Fraction of C } \\
\text { in AA } \\
\\
n_{C, A A, i} \\
\times v_{A A, i} \times 0.01 \\
{[\mathrm{~mol}(\mathrm{~mol}} \\
\left.A A)^{-1}\right]\end{array}$ & $\begin{array}{c}\text { Moles of } \mathbf{N} \\
\text { per mole } \\
\text { AA } \\
n_{N, A A, i} \\
{[\mathrm{~mol}(\mathrm{~mol}} \\
\left.A A)^{-1}\right]\end{array}$ & $\begin{array}{c}\text { Molar } \\
\text { mass of } \\
\mathbf{N} \text { in AA } \\
M_{N, A A, i} \\
{\left[\mathrm{~g} \mathrm{~mol}^{-1}\right]}\end{array}$ & $\begin{array}{c}\text { Fraction of } \\
\mathbf{N} \text { in AA } \\
\\
n_{N, A A, i} \\
\times v_{A A, i} \times 0.01 \\
{[m o l} \\
A(m o l \\
\left.A A)^{-1}\right]\end{array}$ \\
\hline Alanine & 89.1 & 10.06 & 8.96 & 3 & 36.03 & 0.30 & 1 & 14 & 0.10 \\
\hline Arginine & 174.2 & 5.88 & 10.24 & 6 & 72.06 & 0.35 & 4 & 56 & 0.24 \\
\hline Asparagine & 132.1 & 3.58 & 4.73 & 4 & 48.04 & 0.14 & 2 & 28 & 0.072 \\
\hline Aspartate & 133.1 & 5.59 & 7.44 & 4 & 48.04 & 0.22 & 1 & 14 & 0.056 \\
\hline Cysteine & 121.2 & 0.94 & 1.14 & 3 & 36.03 & 0.03 & 1 & 14 & 0.009 \\
\hline Glutamate & 147.1 & 6.15 & 9.05 & 5 & 60.05 & 0.31 & 1 & 14 & 0.062 \\
\hline Glutamine & 146.2 & 3.58 & 5.23 & 5 & 60.05 & 0.18 & 2 & 28 & 0.072 \\
\hline Glycine & 75.1 & 7.76 & 5.83 & 2 & 24.02 & 0.16 & 1 & 14 & 0.078 \\
\hline Histidine & 155.2 & 2.06 & 3.20 & 6 & 72.06 & 0.12 & 3 & 42 & 0.062 \\
\hline Isoleucine & 131.2 & 5.89 & 7.73 & 6 & 72.06 & 0.35 & 1 & 14 & 0.059 \\
\hline Leucine & 131.2 & 10.09 & 13.2 & 6 & 72.06 & 0.61 & 1 & 14 & 0.10 \\
\hline Lysine & 146.2 & 4.68 & 6.84 & 6 & 72.06 & 0.28 & 2 & 28 & 0.094 \\
\hline Methionine & 149.2 & 2.38 & 3.55 & 5 & 60.05 & 0.12 & 1 & 14 & 0.024 \\
\hline Phenylalanine & 165.2 & 3.89 & 6.43 & 9 & 108.09 & 0.35 & 1 & 14 & 0.039 \\
\hline Proline & 115.1 & 4.61 & 5.31 & 5 & 60.05 & 0.23 & 1 & 14 & 0.046 \\
\hline Serine & 105.1 & 5.85 & 6.15 & 3 & 36.03 & 0.18 & 1 & 14 & 0.059 \\
\hline Threonine & 119.1 & 5.52 & 6.57 & 4 & 48.04 & 0.22 & 1 & 14 & 0.055 \\
\hline Tryptophan & 204.2 & 1.27 & 2.59 & 11 & 132.11 & 0.14 & 2 & 28 & 0.025 \\
\hline Tyrosine & 181.2 & 2.94 & 5.33 & 9 & 108.09 & 0.26 & 1 & 14 & 0.029 \\
\hline Valine & 117.1 & 7.27 & 8.51 & 5 & 60.05 & 0.36 & 1 & 14 & 0.073 \\
\hline $\begin{array}{l}\text { Average molar } \\
\text { mass of } A A \text {, } \\
M^{p v}{ }_{A A} \text { (b) }\end{array}$ & 128.07 & & & & & & & & \\
\hline $\begin{array}{l}\text { Average moles } \\
\text { of } C \text { per mole } \\
A A, p^{a v}{ }_{C, A A}(c)\end{array}$ & & & & 4.92 & & & & & \\
\hline $\begin{array}{l}\text { Average moles } \\
\text { of } N \text { per mole } \\
A A, p^{a v}{ }_{N, A A}(d)\end{array}$ & & & & & & & 1.35 & & \\
\hline
\end{tabular}

(a) average abundance of amino acids determined from 3776 bacterial proteomes ${ }^{14}$;

(b) $M_{\mathrm{AA}}^{\mathrm{av}}=\sum_{i=1}^{N} M_{\mathrm{AA}, i} \cdot v_{\mathrm{AA}, i} \cdot 0.01$;

(c) $n_{\mathrm{C}, \mathrm{AA}}^{\mathrm{av}}=\sum_{i=1}^{N} n_{\mathrm{C}, \mathrm{AA}, i} \cdot v_{\mathrm{AA}, i} \cdot 0.01$;

(d) $n_{\mathrm{N}, \mathrm{AA}}^{\mathrm{av}}=\sum_{i=1}^{N} n_{\mathrm{N}, \mathrm{AA}, i} \cdot v_{\mathrm{AA}, i} \cdot 0.01$ 


\section{S4. Model implementation}

\section{S4.1 Initial conditions}

The initial concentration was $50 \mathrm{mg} \mathrm{L}^{-1}{ }^{13} \mathrm{C}_{3^{-}}{ }^{-15} \mathrm{~N}$-glyphosate. This was converted into amounts of ${ }^{13} \mathrm{C}_{3}-{ }^{-15} \mathrm{~N}$-glyphosate added to the system using the volume of water added to the system $(90 \mathrm{~mL})$ :

$$
n=C \times \frac{V}{M}=50 \mathrm{mg} \mathrm{L}^{-1} \times \frac{0.09 \mathrm{~L}}{173.07 \mathrm{~g} \mathrm{~mol}^{-1}}=0.026 \mathrm{mmol}=26.0 \mu \mathrm{mol}
$$

This also corresponds to the amounts of ${ }^{15} \mathrm{~N}$ added. $78 \mu \mathrm{mol}{ }^{13} \mathrm{C}$ were added to the system, as there are three moles of ${ }^{13} \mathrm{C}$ per mole of glyphosate.

The measured values were converted from relative to absolute values by multiplying the percentage of label in the compound with the initial amounts added. The percentages have been corrected with regard to the recovery. The measurements at day 0 can be seen in Table S3.

Table S3: Measurement of the label distribution in the system at day 0.4

\begin{tabular}{l|rrrr}
\hline & ${ }^{13} \mathrm{C}_{3}-{ }^{15} \mathrm{~N}-$ & ${ }^{13} \mathrm{C}_{3}-{ }^{15} \mathrm{~N}-$ & ${ }^{13} \mathrm{C}^{-15} \mathrm{~N}-$ & ${ }^{13} \mathrm{C}-{ }^{15} \mathrm{~N}-\mathrm{AMPA}$ \\
& Glyphosate & Glyphosate & AMPA & \\
& $\%{ }^{13} \mathrm{C}$ & $\mu \mathrm{mol}$ & $\%$ & $\mu \mathrm{mol}$ \\
\hline $\mathrm{m}_{\mathrm{W}}(0)$ & 7.8 & 20.48 & 0.48 & 0.12 \\
$\mathrm{~m}_{\mathrm{D}}(0)+\mathrm{m}_{\mathrm{A}}(0)$ & 15.2 & 3.95 & 0 & 0 \\
$\mathrm{~m}_{\mathrm{S}}(0)$ & 5.64 & 1.44 & 0 & 0 \\
\hline
\end{tabular}

Furthermore, it was assumed that the dissolved organic matter measured in the creek water used for the experimental setup was equal to the concentration of dissolved organic matter in both the water compartment $(\mathrm{W})$ and in the sediment pore water (D).

\section{S4.2 Compartment volumes}

The sediment was found to be composed of $38 \%$ sand and $62 \%$ clay and silt. This means that the sediment can be classified as silty clay or clay and considered "fine textured." ${ }^{19}$ Assuming a solid particle density of $2.5 \mathrm{~kg} \mathrm{~L}^{-1}$, gives a dry volume of

$$
V_{\text {dry }}=\frac{m_{\mathrm{s}}^{\text {dry }}}{\rho_{s}}=\frac{50 \mathrm{~g}}{2.5 \mathrm{~kg} \mathrm{~L}^{-1}}=0.02 \mathrm{~L}
$$


159 The total volume of water in the system was $0.09 \mathrm{~L}$. The total mass of sediment was $50 \mathrm{~g}$ dry

160 weight. The volume of the flask was $250 \mathrm{~mL}$. The bottom diameter was $5.8 \mathrm{~cm}$ for the first $0.3 \mathrm{~cm}$,

161 then it increased to $6.2 \mathrm{~cm}$.

$$
\begin{aligned}
& A_{0 \rightarrow 0.3 \mathrm{~cm}}=\left(\frac{5.8}{2}\right)^{2} \times \pi=29.4 \mathrm{~cm}^{2} \\
& A_{0.3 \mathrm{~cm} \rightarrow}=\left(\frac{6.2}{2}\right)^{2} \times \pi=30.2 \mathrm{~cm}^{2}
\end{aligned}
$$

162 The height of the wet sediment was measured to be approximately $1.3 \mathrm{~cm}$. This gives a volume of

$$
V_{\text {wet sediment }}=A_{0 \rightarrow 0.3 \mathrm{~cm}} \times 0.3+A_{0.3 \mathrm{~cm} \rightarrow} \times 1=38.12 \mathrm{~cm}^{3}=0.38 \mathrm{~L}
$$

163 This results in a bulk density of

$$
\rho_{b}=\frac{50 \mathrm{~g}}{38.12 \mathrm{~cm}^{3}}=1.31 \mathrm{~g} \mathrm{~cm}^{-3}=1.31 \mathrm{~kg} \mathrm{~L}^{-1}
$$

164 The porosity can be determined from

$$
\phi=1-\frac{\rho_{b}}{\rho_{s}}=1-\frac{1.31}{2.5}=0.475
$$

165 The total volume of water in the system is made up of water above the sediment and water in the 166 pore volume of the sediment. The volume of the pore water is

$$
V_{p w}=V_{\text {wet sediment }} \times \phi=38.12 \mathrm{~cm}^{3} \times 0.475=18.11 \mathrm{~cm}^{3}=0.018 \mathrm{~L}
$$

167 And results in a water volume above the sediment of

$$
\begin{gathered}
V_{\mathrm{W}, \text { total }}=V_{\mathrm{W}}+V_{\mathrm{PW}} \Rightarrow V_{W}=90 \mathrm{~cm}^{3}-18.11 \mathrm{~cm}^{3}=71.88 \mathrm{~cm}^{3} \\
=0.0719 \mathrm{~L}
\end{gathered}
$$

168 This corresponds to a water height of

$$
L_{\text {water }}=\frac{71.88 \mathrm{~cm}^{3}}{30.2 \mathrm{~cm}^{2}}=2.38 \mathrm{~cm}
$$

169 Shrestha et al. ${ }^{20}$ showed that $\mathrm{O}_{2}$ did not penetrate more than $2 \mathrm{~mm}$ into the sediment in a

170 comparable OECD 308 test system. Similarly, the penetration depth of glyphosate and AMPA, as

171 calculated using the equations presented in Appendix 9 of the FOCUS document ${ }^{21}$ showed low 172 penetration depth into the sediment. 
$Z_{\mathrm{D}}=\sqrt{2 \times D \times f \times t \times \frac{1}{1+K_{\mathrm{OC}} \times f_{\mathrm{OC}} \times \frac{\rho_{\mathrm{b}}}{\theta}}}$

173 where $Z_{D}$ is the penetration depth in meters, $D$ is the diffusion coefficient in the free solution [ $\mathrm{m}^{2}$

$174 \mathrm{~d}^{-1}$ ], $f$ is the tortuosity factor, $t$ is the experimental time scale (=80 days), $K_{\mathrm{oc}}$ is the adsorption

175 coefficient to organic matter $\left[\mathrm{L} \mathrm{kg}^{-1}\right]$, $f_{\mathrm{oc}}$ is the organic content $(85 \mathrm{mg} / \mathrm{g}) \rho_{\mathrm{b}}$ is the bulk density of

176 the sediment [kg L$\left.{ }^{-1}\right]$, and $\theta$ is the sediment porosity [-]. A constant concentration at the top of the

177 sediment is assumed in the derivation of the equation. This is of course not true. Moreover, the

178 equation does not take degradation into account. Consequently, the equation can be expected to

179 provide an overestimation of the penetration depth.

180 The Koc values used for the calculation were taken from Annex B.8 of the Renewal Assessment

181 Report for glyphosate ${ }^{22}$. The average $K_{\mathrm{oc}}$ value reported for glyphosate was $14,236 \mathrm{~L} \mathrm{~kg}^{-1}$ with a

182 minimum value of $884 \mathrm{~L} \mathrm{~kg}^{-1}$ and a maximum value of $50,660 \mathrm{~L} \mathrm{~kg}^{-1}$. For AMPA, the reported

183 values using the Freundlich isotherm were used. The average $K_{0 c}$ value reported for AMPA was

$1849,749 \mathrm{~L} \mathrm{~kg}^{-1}$ with a minimum value of $1,119 \mathrm{~L} \mathrm{~kg}^{-1}$ and a maximum value of $45,900 \mathrm{~L} \mathrm{~kg}^{-1}$.

185 Using the average values, the penetration depth of glyphosate and AMPA were $1.1 \mathrm{~mm}$ and 1.5

$186 \mathrm{~mm}$, respectively. To simplify matters, it was assumed that the penetration depth of both

187 compounds were $1 \mathrm{~mm}$. This reduces the "effective" pore water and sediment volume to roughly

$18810 \%$ of the volume it occupies in the test system. The approach is comparable to model $\mathrm{B}$ and $\mathrm{C}$ in

189 Honti and Fenner ${ }^{23}$, where the penetration depth, which increases with time, defines the volume in

190 which transformation can take place. It should be noted, that we estimated the Koc of AMPA from

191 the experimental data and the Koc of glyphosate is a parameter fitted by the optimization routine.

192 The estimated and fitted Koc-values for both AMPA and glyphosate were lower than the values

193 used to estimate the penetration depth (see S4.4). 
194 Table S4: Summary of compartment volumes, sediment porosity and density, and amount of ${ }^{13} \mathrm{C}$ 195 and ${ }^{15} \mathrm{~N}$ added to the system.

$$
\text { Unit } \quad{ }^{13} \mathrm{C}_{3}-{ }^{15} \mathrm{~N}-
$$

Glyphosate

\begin{tabular}{|c|c|c|}
\hline Initial concentration in the system & $\mathrm{mg} \mathrm{L}^{-1}$ & 50 \\
\hline Water volume, $V_{\text {water }}$ & $\mathrm{L}$ & 0.09 \\
\hline $\begin{array}{l}\text { Water volume above sediment (compartment } \mathrm{W} \text { ), } \\
V_{\mathrm{w}}\end{array}$ & $L$ & 0.0719 \\
\hline $\begin{array}{l}\text { Water volume in sediment pore water } \\
\text { (compartment } D), V_{D}\end{array}$ & $\mathrm{~L}$ & 0.0181 \\
\hline $\begin{array}{l}\text { Water volume in sediment pore water top } 1 \mathrm{~mm} \\
\text { (compartment } \mathrm{D}), V_{\mathrm{D}}^{\text {effective }}\end{array}$ & $\mathrm{L}$ & 0.00143 \\
\hline Sediment mass, dry weight & $g$ & 50 \\
\hline Sediment bulk density, $\rho_{\mathrm{b}}$ (estimated) & $\mathrm{kg} \mathrm{L}^{-1}$ & 1.31 \\
\hline Sediment wet volume, $V_{\text {sediment,wet }}$ & L & 0.038 \\
\hline Sediment volume of the top $1 \mathrm{~mm}, V_{\text {sediment }}{ }^{\text {effective }}$ & L & 0.00302 \\
\hline Solids volume of the top $1 \mathrm{~mm}, V_{A}^{\text {effective }}=V_{S}^{\text {effective }}$ & L & 0.00158 \\
\hline Sediment porosity (estimated), $\varphi$ & & 0.475 \\
\hline Initial amounts ${ }^{13} \mathrm{C}_{3}-{ }^{15} \mathrm{~N}-$ glyphosate injected & $\mu \mathrm{mol}$ & 26 \\
\hline Initial ${ }^{13} \mathrm{C}$ amounts injected & $\mu \mathrm{mol}{ }^{13} \mathrm{C}$ & 78 \\
\hline Initial ${ }^{15} \mathrm{~N}$ amounts injected & $\mu \mathrm{mol}{ }^{15} \mathrm{~N}$ & 26 \\
\hline
\end{tabular}

\section{S4.3 pH dependency}

198 Glyphosate is ionized at both pH 7.1 (sediment) and pH 8.8 (water). At pH 7.1 the predominant 199 form of glyphosate has a negative charge of -2 . The phosphonic acid and carboxylic moieties are 200 deprotonated and the amine group is protonated. Approximately $6 \%$ of the glyphosate molecules 201 have a net charge of -1 . At pH 8.8 the predominant form still has a net charge of -2 , however 202 approximately $6 \%$ of the glyphosate now has a net charge of -3 .

203 AMPA is also ionized at both $\mathrm{pH} 7.1$ and $\mathrm{pH}$ 8.8. At $\mathrm{pH} 7.1$ the predominant form of AMPA has a 204 negative charge of -1 . The phosphonic acid is deprotonated and the amine group is protonated. 205 Approximately $2 \%$ of the AMPA molecules exhibit a net charge of 0 , where the amine group and 206 one of the $-\mathrm{OH}$ groups are charged. At $\mathrm{pH} 8.8$ the predominant form still has a net charge of -1 207 and approximately $3 \%$ exhibit a net charge of -2 , meaning the amine group is not protonated. 


\section{S4.4 Determination of the pore water-adsorbed compartment distribution coefficient}

Assuming that AMPA is an accumulating metabolite, the final measurement of AMPA can be used to calculate the pore water-adsorbed compartment distribution coefficient of AMPA. If the concentration in the water compartment and sediment pore water is the same (the diffusive flux across the boundary layer is zero), then the adsorbed mass is

$$
\begin{gathered}
m_{\mathrm{A}}^{\mathrm{AMPA}}=m_{\text {sediment }}^{\mathrm{AMPA}}-\frac{m_{\mathrm{W}}^{\mathrm{AMPA}}}{V_{\mathrm{W}}} V_{\mathrm{D}}^{\text {effective }} \\
m_{\mathrm{A}}^{\mathrm{AMPA}}=16.5 \mu \mathrm{mol}-\frac{3.9 \mu \mathrm{mol}}{0.071 \mathrm{~L}} 0.00143 \mathrm{~L}=16.4 \mu \mathrm{mol}
\end{gathered}
$$

and the concentration is

$$
C_{\mathrm{A}}^{\mathrm{AMPA}}=\frac{m_{\mathrm{A}}^{\mathrm{AMPA}}}{V_{\mathrm{A}}^{\text {effective }}}=\frac{16.4 \mu \mathrm{mol}}{0.00158 \mathrm{~L}}=10,367 \mu \mathrm{mol} \mathrm{L}^{-1}
$$

The pore water-adsorbed compartment distribution coefficient can be determined:

$$
K_{\mathrm{SPW}}=\frac{C_{\mathrm{A}}}{C_{\mathrm{D}}}=\frac{10,367 \mu \mathrm{mol} \mathrm{L}}{-1}=191.1 \mathrm{~L} \mathrm{~L}^{-1}
$$

Normalizing this with the organic content of the sediment and the bulk density gives the Koc

$$
K_{\mathrm{OC}}^{\mathrm{AMPA}}=\frac{191.1 \mathrm{~L} \mathrm{~L}^{-1}}{1.31 \mathrm{~kg} \mathrm{~L}^{-1} \times 0.085 \mathrm{~g} \mathrm{OC} \mathrm{g}^{-1}}=1,714 \mathrm{~kg} \mathrm{~L}^{-1}
$$

Based on the data collected in Annex B.8 of the Renewal Assessment Report for Glyphosate ${ }^{22}$, the ratio of $K_{\mathrm{oc}}$ of glyphosate and AMPA is 1.535 . This factor was used to delineate the parameter space of the uniform distribution guiding the DREAM optimization algorithm. Using the estimated $K_{\mathrm{OC}}$ for AMPA, a penetration depth of $3.7 \mathrm{~mm}$ can be calculated using Eq. (S28). Nonetheless, 1 $\mathrm{mm}$ was still chosen as the "active" depth of the sediment for AMPA.

\section{S4.5 Mathematical description of the system}

In the manuscript, only microbial metabolism, degradation of glyphosate and formation of $\mathrm{CO}_{2}$ are described. Here, the equations used to mathematically describe transport across compartments the system are presented.

\section{Diffusion and sorption of glyphosate}

Glyphosate was added to the supernatant water of the experimental system. The change of glyphosate amounts in the supernatant water (compartment W) was described by the diffusive flux to and from the sediment pore water: 
$\frac{\mathrm{d} n_{\mathrm{W}}^{\mathrm{GLP}}}{\mathrm{d} t}=A_{\mathrm{W}} P_{\mathrm{WD}}^{\mathrm{GLP}}\left(a_{\mathrm{D}}^{\mathrm{GLP}}-a_{\mathrm{W}}^{\mathrm{GLP}}\right)$

229 The temporal change of glyphosate amounts dissolved in sediment pore water, $\mathrm{d} n_{D}{ }^{G L P} / \mathrm{d} t[\mu \mathrm{mol}$ $230 \mathrm{~d}^{-1}$ ], was described by the diffusive exchange with supernatant water $(\mathrm{W})$, ad/desorption to/from 231 sediment $(A)$ and microbial degradation via the sarcosine and AMPA pathways:

$\frac{\mathrm{d} n_{\mathrm{D}}^{\mathrm{GLP}}}{\mathrm{d} t}=P_{\mathrm{WD}}^{\mathrm{GLP}} A_{\mathrm{W}}\left(a_{\mathrm{W}}^{\mathrm{GLP}}-a_{\mathrm{D}}^{\mathrm{GLP}}\right)+P_{\mathrm{DA}}^{\mathrm{GLP}} A_{\mathrm{A}}\left(a_{\mathrm{A}}^{\mathrm{GLP}}-a_{\mathrm{D}}^{\mathrm{GLP}}\right)-\frac{\mathrm{d} n_{\mathrm{M}, \mathrm{SRC}}^{\mathrm{GLP}}}{\mathrm{d} t}-\frac{\mathrm{d} n_{\mathrm{M}, \mathrm{AMPA}}^{\mathrm{GLP}}}{\mathrm{d} t}$

232 where $n[\mu \mathrm{mol}]$ is amounts and $a\left[\mu \mathrm{mol} \mathrm{m}^{-3}\right]$ is the chemical activity of glyphosate (superscript 233 GLP) dissolved in sediment pore water (index D), dissolved in supernatant water (W) and 234 adsorbed to sediment $(\mathrm{A}) . A_{W}$ and $A_{A}\left[\mathrm{~m}^{2}\right]$ are the cross sectional areas effective for diffusion and 235 adsorption, respectively. The transfer velocity, also termed permeability, $P_{\mathrm{WD}}^{\mathrm{GLP}}\left[\mathrm{m} \mathrm{d}^{-1}\right]$, for 236 glyphosate diffusion between supernatant water and sediment pore water is defined as $P_{\mathrm{WD}}{ }^{\mathrm{GLP}}=$ $237 D_{\mathrm{W}} / \Delta x_{\mathrm{WD}}$, where $D_{\mathrm{W}}\left[\mathrm{m}^{2} \mathrm{~d}^{-1}\right]$ is the diffusion coefficient of the compound in water and $\Delta x_{\mathrm{WD}}[\mathrm{m}]$ is 238 the boundary layer thickness at the water-sediment interface. $P_{\mathrm{DA}} \mathrm{GLP}\left[\mathrm{m} \mathrm{d}^{-1}\right]$ is the transfer velocity 239 for glyphosate adsorption and is defined as $P_{\mathrm{DA}}^{\mathrm{GLP}}=\mathrm{T}_{\mathrm{T}} / \Delta x_{\mathrm{AD}}$, where $D_{\mathrm{W}}\left[\mathrm{m}^{2} \mathrm{~d}^{-1}\right]$ is the diffusion 240 coefficient of the compound in water and $\Delta x_{\mathrm{AD}}[\mathrm{m}]$ is the diffusion length at the pore water-sediment 241 surface interface, and $\mathrm{T}$ is the tortuosity, which was calculated using the equation of Millington and 242 Quirk ${ }^{24}$ :

$\tau=\frac{\theta^{\frac{10}{3}}}{\epsilon^{2}}=\frac{0.475^{\frac{10}{3}}}{0.475^{2}}=0.371$

243 Where $\theta$ is the water filled porosity, and $\varepsilon$ is the total porosity of the sediment. When the sediment 244 is fully saturated $\theta$ and $\varepsilon$ are equal.

Sorption of glyphosate to sediment organic matter was described using bi-phase first-order equilibrium kinetics. This included rapid ad/desorption between pore water (D) and adsorbed phase (A), followed by slow sequestration/remobilization between adsorbed and sequestered phase (S). These steps were assumed to occur in series, as suggested e.g. by Johnson et al. ${ }^{25}$, Kästner et al. $^{26}$ and Rein et al. ${ }^{27}$ Changes of glyphosate amount adsorbed to sediment and sequestered in the sediment are thus given as:

$$
\begin{gathered}
\frac{\mathrm{d} n_{\mathrm{A}}^{\mathrm{GLP}}}{\mathrm{d} t}=A_{\mathrm{A}} P_{\mathrm{DA}}^{\mathrm{GLP}}\left(a_{\mathrm{D}}^{\mathrm{GLP}}-a_{\mathrm{A}}^{\mathrm{GLP}}\right)-\frac{\mathrm{d} n_{\mathrm{S}}^{\mathrm{GLP}}}{\mathrm{d} t} \\
\frac{\mathrm{d} n_{\mathrm{S}}^{\mathrm{GLP}}}{\mathrm{d} t}=A_{\mathrm{S}} P_{\mathrm{AS}}^{\mathrm{GLP}}\left(a_{\mathrm{A}}^{\mathrm{GLP}} B_{\mathrm{S}}^{\mathrm{GLP}}-a_{\mathrm{S}}^{\mathrm{GLP}} B_{\mathrm{S}}^{\mathrm{GLP}}\right)
\end{gathered}
$$

252 where $n[\mu \mathrm{mol}]$ is amounts and $a\left[\mu \mathrm{mol} \mathrm{m}{ }^{-3}\right]$ is the chemical activity of glyphosate (superscript $253 \mathrm{GLP}$ ) adsorbed to sediment (index $\mathrm{A}$ ) and sequestered in sediment (index $\mathrm{S}$ ). $A_{S}\left[\mathrm{~m}^{2}\right]$ is the cross 254 sectional area effective for sequestration and $P_{\mathrm{AS}}^{\mathrm{GLP}}\left[\mathrm{m} \mathrm{d}^{-1}\right]$ is the transfer velocity of glyphosate 255 between adsorbed and sequestered state and is defined as $P_{\mathrm{AS}}{ }^{\mathrm{GLP}}=D_{\mathrm{S}} / \Delta x_{\mathrm{AS}}$ where $D_{\mathrm{S}}\left[\mathrm{m}^{2} \mathrm{~d}^{-1}\right]$ is 
256 the diffusion coefficient of the compound in sediment (assumed to be $10^{-5}$ of that in water) and $257 \Delta x_{\mathrm{AS}}[\mathrm{m}]$ is the diffusion length into the sediment. $B_{S}{ }^{\mathrm{GLP}}\left[\mathrm{m}^{3} \mathrm{~m}^{-3}\right]$ is the apparent bulk activity 258 capacity of the sequestered compartment, given as $B_{\mathrm{S}}{ }^{\mathrm{GLP}}=K_{\mathrm{d}, \mathrm{S}}{ }^{\mathrm{GLP}} \times \rho_{\mathrm{S}}$, where $K_{\mathrm{d}, \mathrm{S}}{ }^{\mathrm{GLP}}\left[\mathrm{L}\right.$ water kg ${ }^{-1}$ 259 soil] is the glyphosate soil-water partition coefficient in compartment $S$ and $\rho_{S}\left[\mathrm{~kg} \mathrm{~L}^{-1}\right]$ is the density 260 of compartment S (Trapp et al. 2010).

\section{Diffusion and sorption of AMPA}

AMPA is formed from glyphosate degradation (metabolic flux $d n_{M}$, AMPA $\mathrm{GLP} / \mathrm{d} t$, Eq. 14) and can diffuse to the supernatant water layer and ad/desorb to/from sediment:

$\frac{\mathrm{d} n_{\mathrm{D}}^{\mathrm{AMPA}}}{\mathrm{d} t}=+\frac{\mathrm{d} n_{\mathrm{M}, \mathrm{AMPA}}^{\mathrm{GLP}}}{\mathrm{d} t}-P_{\mathrm{WD}}^{\mathrm{AMPA}} A_{\mathrm{W}}\left(a_{\mathrm{D}}^{\mathrm{AMPA}}-a_{\mathrm{W}}^{\mathrm{AMPA}}\right)-P_{\mathrm{DA}}^{\mathrm{AMPA}} A_{\mathrm{A}}\left(a_{\mathrm{A}}^{\mathrm{AMPA}}-a_{\mathrm{D}}^{\mathrm{AMPA}}\right)$

where $n[\mu \mathrm{mol}]$ is amounts and $a\left[\mu \mathrm{mol} \mathrm{m}{ }^{-3}\right]$ is the chemical activity of AMPA (superscript AMPA) dissolved in sediment pore water (index $D$ ), dissolved in supernatant water $(W)$ and adsorbed to sediment $(\mathrm{A}), P_{\mathrm{DA}} \mathrm{AMPA}\left[\mathrm{m} \mathrm{d}^{-1}\right]$ is transfer velocity for AMPA sorption, and other parameters are given above. Degradation of AMPA was not considered in the model: differentiating between AMPA formation (from glyphosate degradation) and AMPA degradation was not possible from the reported experimental results (Wang et al. 2016). Moreover, the experimental observations did not indicate AMPA degradation as no increased incorporation of ${ }^{15} \mathrm{~N}$ into amino acids or NER were observed when the amount of extractable glyphosate reached a (pseudo) steady-state.

Amounts of AMPA dissolved in supernatant water (W) and AMPA adsorbed to sediment (A) and sequestered in sediment $(S)$ are given as:

$\frac{\mathrm{d} n_{\mathrm{W}}^{\mathrm{AMPA}}}{\mathrm{d} t}=A_{\mathrm{W}} P_{\mathrm{WD}}^{\mathrm{AMPA}}\left(a_{\mathrm{D}}^{\mathrm{AMPA}}-a_{\mathrm{W}}^{\mathrm{AMPA}}\right)$

$\frac{\mathrm{d} n_{\mathrm{A}}^{\mathrm{AMPA}}}{\mathrm{d} t}=A_{\mathrm{A}} P_{\mathrm{DA}}^{\mathrm{AMPA}}\left(a_{\mathrm{D}}^{\mathrm{AMPA}}-a_{\mathrm{A}}^{\mathrm{AMPA}}\right)-\frac{\mathrm{d} n_{\mathrm{S}}^{\mathrm{AMPA}}}{\mathrm{d} t}$

$\frac{\mathrm{d} n_{\mathrm{S}}^{\mathrm{AMPA}}}{\mathrm{d} t}=A_{\mathrm{S}} P_{\mathrm{AS}}^{\mathrm{AMPA}}\left(a_{\mathrm{A}}^{\mathrm{AMPA}} B_{\mathrm{S}}^{\mathrm{AMPA}}-a_{\mathrm{S}}^{\mathrm{GLP}} B_{\mathrm{S}}^{\mathrm{AMPA}}\right)$

where parameters refer to AMPA (superscript AMPA), however processes are analogous to those described above for glyphosate. The ${ }^{13} \mathrm{C}-\mathrm{NER} /{ }^{15} \mathrm{~N}-\mathrm{NER}$ ratio was $>3$ except for the final measurement, indicating negligible incorporation of AMPA into the NER compartment. Considerable incorporation of AMPA into NER would displace the ratio towards 1. Consequently, it was assumed, that AMPA did not form NER in the experiment and its sequestration was therefore set equal to zero. 
283 Table S5: Complete list of input parameters for the two-compartment-adsorption model used to 284 simulate the mineralization and non-extractable residue formation of ${ }^{13} \mathrm{C}_{3}-{ }^{15} \mathrm{~N}$-glyphosate in a 285 water-sediment system.

\begin{tabular}{|c|c|c|c|c|}
\hline & Unit & $\begin{array}{l}{ }^{13} \mathrm{C}_{3}-{ }^{15} \mathrm{~N}- \\
\text { Glyphosate }\end{array}$ & & $\begin{array}{l}{ }^{13} \mathrm{C}-{ }^{15} \mathrm{~N}- \\
\text { AMPA }\end{array}$ \\
\hline \multicolumn{5}{|l|}{ Compound } \\
\hline Molecular mass of unlabeled compound & $\mathrm{g} \mathrm{mol}^{-1}$ & & 169 & 111 \\
\hline Molecular mass of labeled compound & $\mathrm{g} \mathrm{mol}^{-1}$ & & 173 & 113 \\
\hline $\mathrm{mol}{ }^{13} \mathrm{C}$ (mol compound $)^{-1}$ & & & 3 & 1 \\
\hline $\mathrm{mol}^{13} \mathrm{~N}$ (mol compound $)^{-1}$ & & & 1 & 1 \\
\hline \multicolumn{5}{|l|}{ Microorganisms } \\
\hline$v_{\text {max }, \mathrm{SRC}}$ & $\begin{array}{l}\mu \mathrm{mol}(\mu \mathrm{mol} \\
\text { bacteria d })^{-1}\end{array}$ & & 2.56 & \\
\hline$K_{\mathrm{S}, \mathrm{SRC}}$ & $\mu \mathrm{mol} \mathrm{L} \mathrm{L}^{-1}$ & & 391 & \\
\hline$K_{\mathrm{S}}^{\mathrm{N}}$ & $\mu \mathrm{mol} \mathrm{L} \mathrm{L}^{-1}$ & & 47.0 & \\
\hline$v_{\text {max }, \mathrm{AMPA}}$ & $\begin{array}{l}\mu \mathrm{mol}(\mu \mathrm{mol} \\
\text { bacteria d })^{-1}\end{array}$ & & 26.9 & \\
\hline$K_{\mathrm{S}, \mathrm{AMPA}}$ & $\mu \mathrm{mol} \mathrm{L}^{-1}$ & & 1327 & \\
\hline$X(0)$ & $\mu \mathrm{mol} \mathrm{L} \mathrm{L}^{-1}$ & & 0.050 & \\
\hline$\mu_{\max , \mathrm{SRC}}$ & $d^{-1}$ & & 0.713 & \\
\hline$\mu_{\mathrm{max}, \mathrm{AMPA}}$ & $d^{-1}$ & & 2.04 & \\
\hline \multicolumn{5}{|l|}{ Sediment } \\
\hline Bulk density of soil, $\rho_{b}$ & $\mathrm{~kg} \mathrm{~L}^{-1}$ & & 1.31 & \\
\hline Tortuosity & & 0.371 & & 0.371 \\
\hline Diffusion distance in water & $\mathrm{m}$ & $1 \times 10^{-}$ & & $1 \times 10^{-6}$ \\
\hline Diffusion distance in sediment & $\mathrm{m}$ & $5 \times 10^{-}$ & & $5 \times 10^{-6}$ \\
\hline \multicolumn{5}{|l|}{ Compound } \\
\hline Diffusion coefficient of compound in water, $D_{w}$ & $\mathrm{~m}^{2} \mathrm{~s}^{-1}$ & \multicolumn{2}{|c|}{$8.59 \times 10^{-10}$} & $1.06 \times 10^{-9}$ \\
\hline $\begin{array}{l}\text { Effective diffusion coefficient of compound in sediment, } \\
D_{\mathrm{s}}\end{array}$ & $m^{2} s^{-1}$ & \multicolumn{2}{|c|}{$8.59 \times 10^{-15}$} & $1.06 \times 10^{-14}$ \\
\hline Permeability in water, $P_{w}$ & $\mathrm{~m} \mathrm{~s}^{-1}$ & \multicolumn{2}{|c|}{$6.88 \times 10^{-4}$} & $8.51 \times 10^{-4}$ \\
\hline Permeability in sediment, $P_{\mathrm{S}}$ & $\mathrm{m} \mathrm{s}^{-1}$ & \multicolumn{2}{|c|}{$1.72 \times 10^{-9}$} & $2.13 \times 10^{-9}$ \\
\hline$K_{o c}$ & $\mathrm{~L} \mathrm{~kg}^{-1}$ & 882 & (fit) & 1714 \\
\hline \multicolumn{5}{|l|}{ Water } \\
\hline Organic content, $O C_{w}$ & gOC $(g d w ~ s o i l)^{-1}$ & & 0.008 & \\
\hline
\end{tabular}




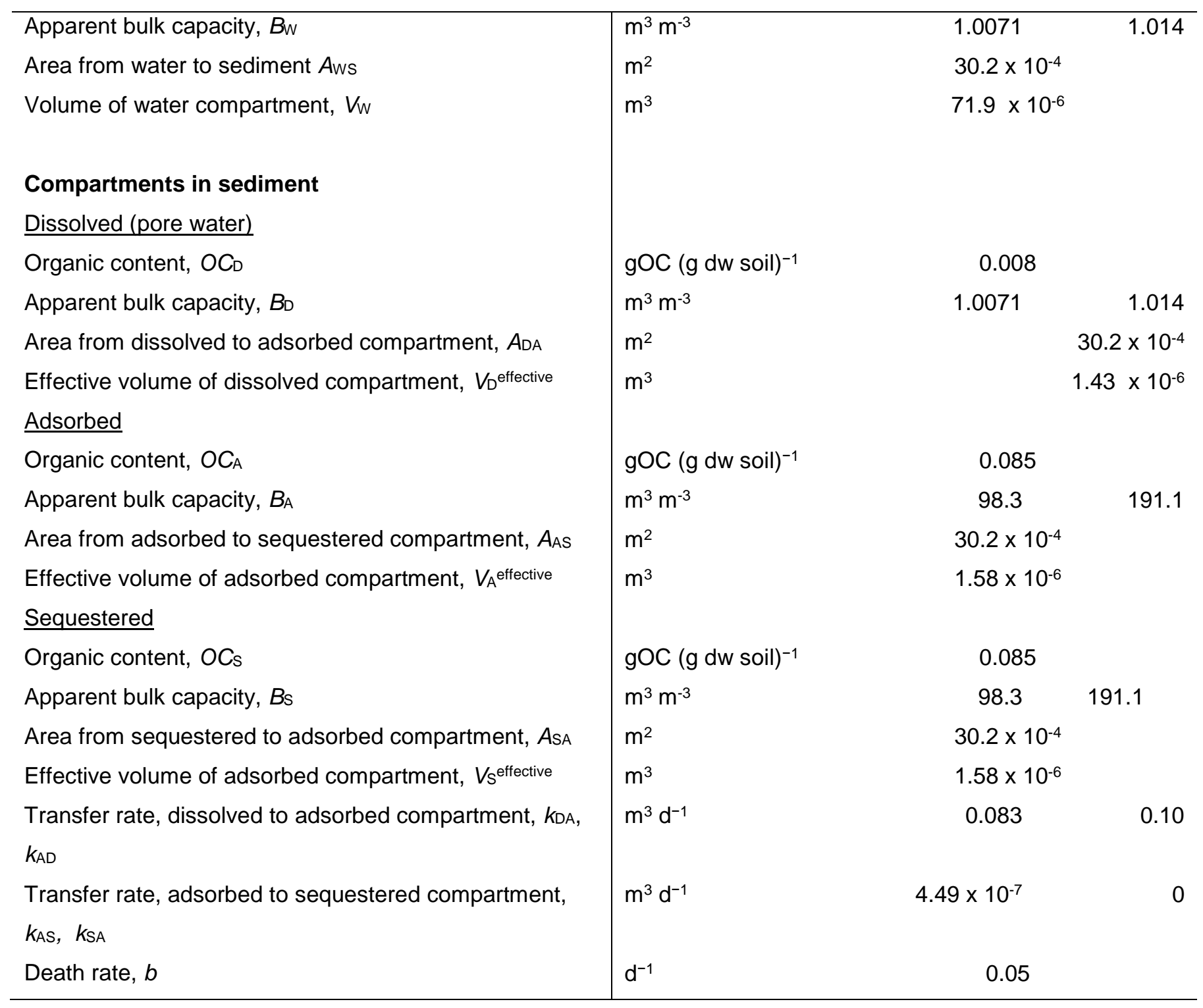




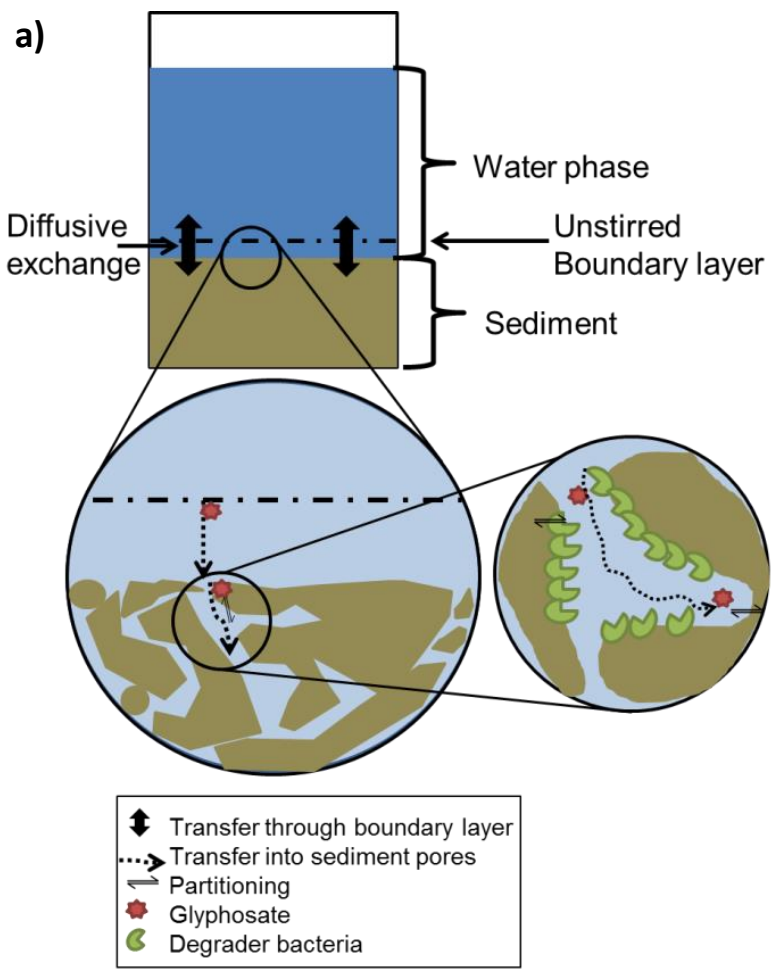

b)

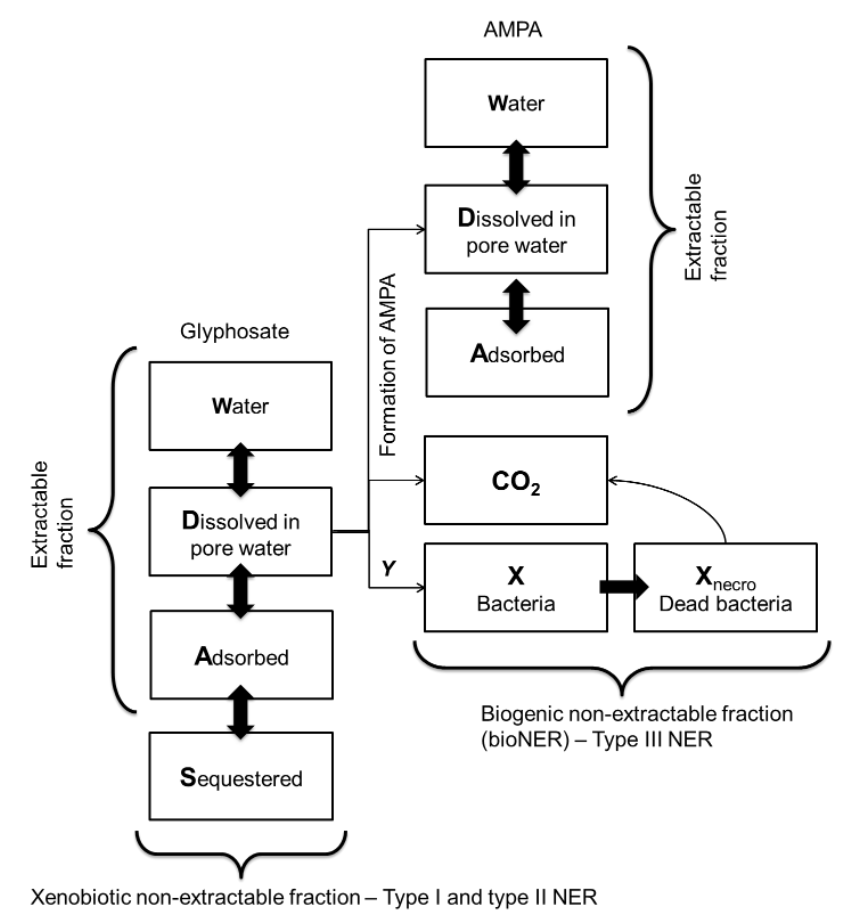

Figure S2: Overview of the OECD 308 experimental test system for simulation of the environmental fate of chemicals and the accompanying model structure. (a) The experimental system consisting of sediment with a stagnant supernatant water layer. Here, glyphosate diffuses across the unstirred boundary layer from the water to the sediment and back. In the sediment, glyphosate and its metabolites can be degraded, adsorb to the sediment particles or are sequestered into the particles over time; (b) Model structure. In the sediment, glyphosate is dissolved in the pore water $(\boldsymbol{D})$, adsorbed to the sediment particles $(\boldsymbol{A})$ or sequestered in the particles (S). AMPA was dissolved or adsorbed and assumed to not be sequestered and not form NER as the $\mathrm{C} / \mathrm{N}$ ratio of the NER $(\mathrm{C} / \mathrm{N}>3)$ exceeded that of AMPA (C/N equal to 1$)$. Only dissolved glyphosate is available to the bacteria $(\boldsymbol{X})$ and is metabolized to biomass and AMPA or mineralized to $\mathrm{CO}_{2}$. The bacteria die and form necromass (dead bacteria, $\boldsymbol{X}_{\text {necro }}$ ) which is slowly oxidized to $\mathrm{CO}_{2}$. 


\section{S5. DREAM parameter optimization and uncertainty analysis}

Out of the more than 30 input parameters of the model (Table S5), seven were estimated using the Bayesian optimization method DiffeRential Evolution Adaptive Metropolis algorithm (DREAM). ${ }^{28}$ The method is based on Markov chain Monte Carlo. Noninformative uniform prior distributions were assumed for all parameters because no prior information was available to justify more complex distributions. Previously reported values guided the delineation of the upper and lower boundaries of the uniform distributions. , $, 6,29$

The pooled residual sum of squares residuals (RSS) was used as the objective function:

$$
p R S S(j)=\sum_{j}^{N} \sum_{i=1}^{n}\left(O_{i, j}-P_{i, j}\right)^{2}
$$

Where $j \ldots . . N$ denote the state variables $\left(\mathrm{CO}_{2}\right.$; total NER; glyphosate in compartments $W, D, A$, and $S$; AMPA in compartments $W, D, A), i \ldots n$ are the number of data points, $O_{i, j}$ is the observed data and $P_{i, j}$ is the prediction of state variable $j$ at time $i$. Only the ${ }^{13} \mathrm{C}$ measurements were used for the optimization. Also, the root-mean square error was used to evaluate the performance of the optimal parameter set.

The initial parameter sampling was done using a Latin hypercube. 10 Markov chains were each run for 10,000 generations to find the optimal parameter set describing the observations (in total 100,000 generations). The average acceptance rate of the final 25,000 generations was $12 \%$. The first $75 \%$ of the generations were considered part of the burn-in period and discarded. The default settings of the DREAM v3.028 were used. The log-likelihood function (DREAMPar.lik = 11), residual sum of squares, was employed:

$$
\mathcal{L}(\mathbf{x} \mid \widetilde{\mathbf{Y}})=-\frac{n}{2} \log \left(\sum_{i=1}^{n} e(\mathbf{x})^{2}\right)
$$

were $\mathcal{L}(\mathrm{x} \mid \widetilde{\mathbf{Y}})$ denotes the log-likelihood function of the parameters, $\mathbf{x}$, given the observations $\widetilde{\mathbf{Y}}, e(\mathbf{x})$ is the error between observation and model prediction, $n$ is the number of observations and comes from the derivation of the likelihood function which assumes a Gaussian distribution. It can here be seen as a constant scaling factor. 
325 Table S6: Range of prior uniform distributions used in the DREAM parameter optimization, mean, 326 standard deviation and coefficient of variation of the resulting posterior distributions.

\begin{tabular}{|c|c|c|c|c|c|}
\hline Parameter & Unit & $\begin{array}{l}\text { Range of prior } \\
\text { distribution }\end{array}$ & $\begin{array}{l}\text { Mean, } \\
\mu\end{array}$ & $\begin{array}{l}\text { Standard } \\
\text { deviation, } \sigma\end{array}$ & $\begin{array}{l}\text { Coefficient of } \\
\text { variation } \sigma / \mu\end{array}$ \\
\hline \multirow{2}{*}{$v_{\max , \mathrm{SRC}}$} & $\mu \mathrm{mol}(\mu \mathrm{mol}$ & $0.01-80$ & & & \\
\hline & bacteria $\mathrm{d})^{-1}$ & & 1.93 & 0.75 & $39 \%$ \\
\hline$K_{\mathrm{S}, \mathrm{SRC}}$ & $\mu \mathrm{mol} \mathrm{L}{ }^{-1}$ & $23-400$ & 270.5 & 95.8 & $35 \%$ \\
\hline$K_{\mathrm{OC}, \mathrm{GLP}}$ & $\mathrm{L} \mathrm{kg}^{-1}$ & $322-2571$ & 903 & 83.7 & $9 \%$ \\
\hline \multirow[t]{2}{*}{$v_{\text {max }, \mathrm{AMPA}}$} & $\mu \mathrm{mol}(\mu \mathrm{mol}$ & $0.5-30$ & & & \\
\hline & bacteria $d)^{-1}$ & & 20.9 & 6.3 & $30 \%$ \\
\hline$K_{\mathrm{S}, \mathrm{AMPA}}$ & $\mu \mathrm{mol} \mathrm{L} \mathrm{L}^{-1}$ & $400-1500$ & 1044 & 308 & $29 \%$ \\
\hline$K_{\mathrm{S}}^{\mathrm{N}}$ & $\mu \mathrm{mol} \mathrm{L} \mathrm{L}^{-1}$ & $1-79$ & 41.5 & 23.1 & $56 \%$ \\
\hline$X(0)$ & $\mu \mathrm{mol} \mathrm{L}^{-1}$ & $0.01-1$ & 0.06 & 0.03 & $45 \%$ \\
\hline
\end{tabular}

328 Table S7: Correlation matrix obtained by the parameter fitting in the DREAM parameter 329 optimization.

\begin{tabular}{|c|c|c|c|c|c|c|c|}
\hline & $v_{\max , \mathrm{SRC}}^{\mathrm{GLP}}$ & $K_{\mathrm{S}, \mathrm{SRC}}$ & $K_{\mathrm{OC}, \mathrm{GLP}}$ & $v_{\text {max,AMPA }}$ & $K_{\mathrm{S}, \mathrm{AMPA}}$ & $K_{\mathrm{S}}^{\mathrm{N}}$ & $X(0)$ \\
\hline$v_{\max , \mathrm{SRC}}$ & 1.00 & & & & & & \\
\hline$K_{\mathrm{S}, \mathrm{SRC}}$ & 0.87 & 1.00 & & & & & \\
\hline$K_{\mathrm{OC}, \mathrm{GLP}}$ & 0.28 & 0.13 & 1.00 & & & & \\
\hline$v_{\text {max,AMPA }}$ & 0.21 & 0.20 & 0.17 & 1.00 & & & \\
\hline$K_{\mathrm{S}, \mathrm{AMPA}}$ & 0.22 & 0.19 & -0.06 & 0.89 & 1.00 & & \\
\hline$K_{\mathrm{S}}^{\mathrm{N}}$ & -0.07 & 0.05 & -0.10 & -0.13 & -0.12 & 1.00 & \\
\hline$X(0)$ & -0.55 & -0.33 & -0.21 & -0.41 & -0.30 & 0.50 & 1.00 \\
\hline
\end{tabular}


(a)

332

333

(e)
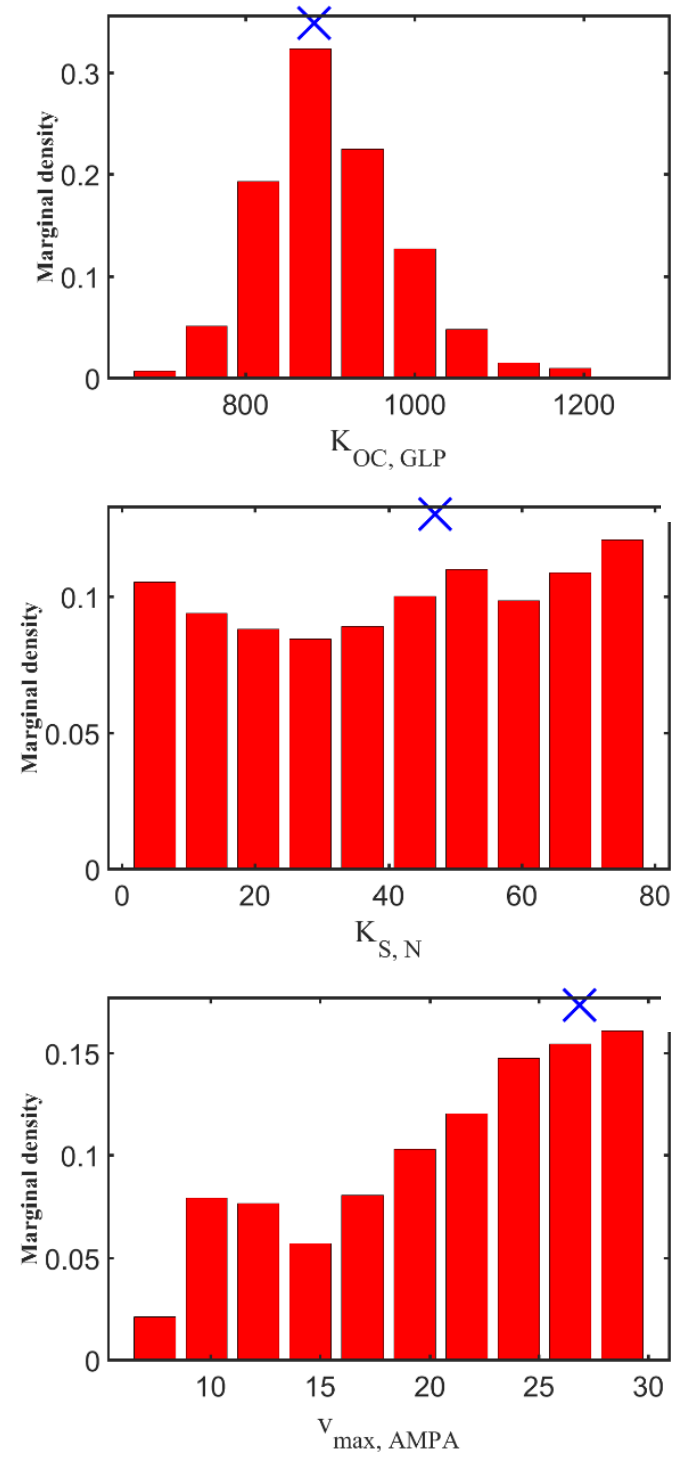

(c)

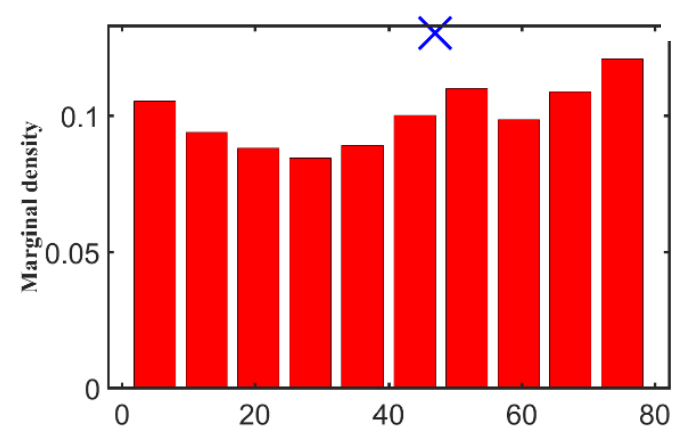

(b)

(d)
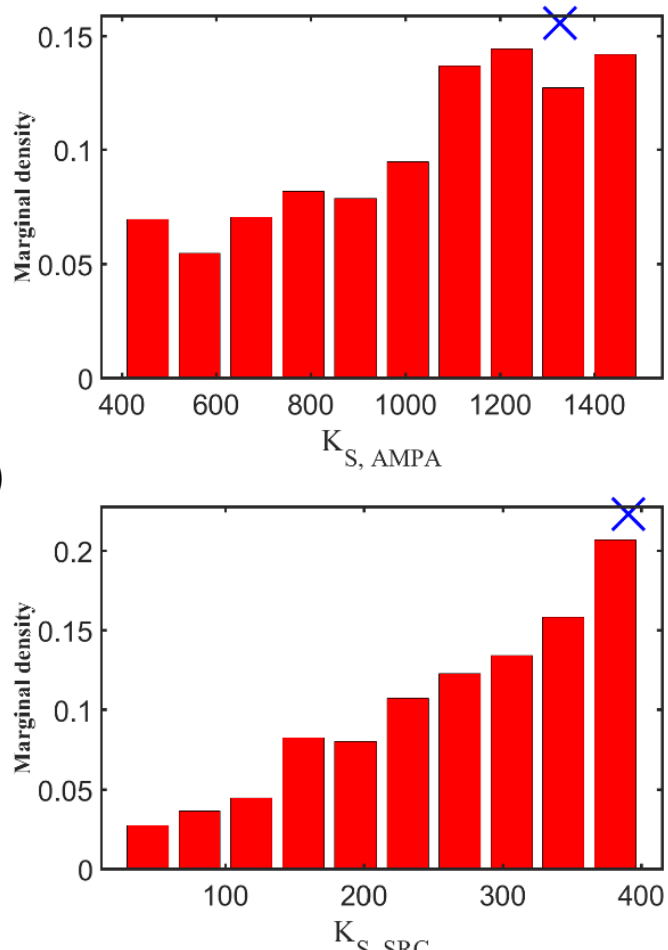

(f)

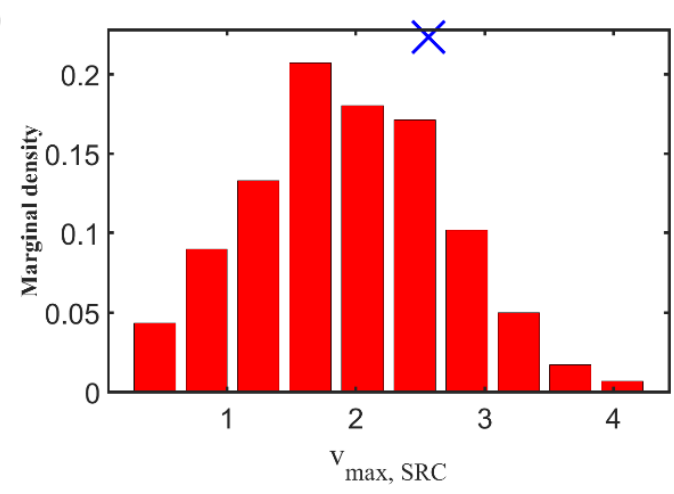

336 Figure S3: Histograms showing the posterior distribution of the estimated parameters: (a) KOC,GLP,

337 (b) $K_{\mathrm{S}, \mathrm{AMPA}},(\mathbf{c}) K_{\mathrm{S}, \mathrm{N}},(\mathbf{d}) K_{\mathrm{S}, \mathrm{SRC}}(\mathbf{e}) v_{\mathrm{max}}$ AMPA, (f) $v_{\max }$ SRC, and (g) $X(0)$. The blue crosses indicate the 338 location of the parameter value providing the maximum a-posterior probability (optimal parameter 339 set).

S6. Testing of alternative hypotheses. 
The model has also been used to test the following two alternative hypotheses:

342

1) The sarcosine pathway is subject to competitive inhibition from the phosphate released in the same pathway.

2) AMPA is degradable under the experimental conditions and the sarcosine pathway is competitively inhibited by ortho-phosphate.

S6.1 Alternative hypothesis 1 is addressed in the model by including a process for the competitive inhibition by ortho-phosphate released in the first step of the sarcosine pathway (cf. Eq. (S1) and Eq. (11)):

$\frac{\mathrm{d} n_{\mathrm{M}, \mathrm{SRC}}}{\mathrm{d} t}=v_{\text {max }, \mathrm{SRC}} \frac{a_{\mathrm{D}}}{a_{\mathrm{D}}+K_{\mathrm{S}, \mathrm{SRC}}\left(1+\frac{a_{\mathrm{D}}^{\mathrm{P}}}{K_{\mathrm{I}}}\right)} X$

Where $a_{\mathrm{D}}^{\mathrm{P}}$ is the chemical activity of phosphate (freely dissolved concentration [ $\left.\mu \mathrm{mol} \mathrm{L}^{-1}\right]$, and identical to $a_{\mathrm{D}}^{\mathrm{N}}$ ), and $K_{\mathrm{l}}$ is the inhibition coefficient $\left[\mu \mathrm{mol} \mathrm{L}^{-1}\right]$. Conversely, the dependence of nitrogen released is removed from the equation describing the AMPA formation (Eq. (12)):

$\frac{\mathrm{d} n_{\mathrm{M}, \mathrm{AMPA}}}{\mathrm{d} t}=v_{\text {max,AMPA }} \frac{a_{\mathrm{D}}}{a_{\mathrm{D}}+K_{\mathrm{S}, \mathrm{AMPA}}} X$

From the experimental mass balance, a maximum of $6.4 \mu \mathrm{mol}$ of $\mathrm{P}_{\mathrm{i}}$ are released as this corresponds to the amount of glyphosate not processed via the AMPA pathway (see S7 and S8). What has not been included in the model is the diffusion of $P_{i}$ into the stagnant water layer, any influence of uptake by glyphosate degrading bacteria or other organisms, and sorption to solid particles. As such, the approach takes the form of a 'worst-case' scenario with all released $\mathrm{P}_{\mathrm{i}}$ being freely dissolved in the top $1 \mathrm{~mm}$ of the sediment.

The outcome of the DREAM parameter optimization can be seen in Table S8. The RMSE of the optimum parameter set was $2.1 \mu \mathrm{mol}$. 
Table S8: Range of prior uniform distributions used in the DREAM parameter optimization, and mean, standard deviation and coefficient of variation of the resulting posterior distributions for alternative hypothesis 1: competitive inhibition.

\begin{tabular}{|c|c|c|c|c|c|c|}
\hline Parameter & Unit & $\begin{array}{l}\text { Range of prior } \\
\text { distribution }\end{array}$ & Optimum & $\begin{array}{l}\text { Mean, } \\
\mu\end{array}$ & $\begin{array}{l}\text { Standard } \\
\text { deviation, } \sigma\end{array}$ & $\begin{array}{l}\text { Coefficient of } \\
\text { variation } \sigma / \mu\end{array}$ \\
\hline$v_{\max , \mathrm{SRC}}$ & $\begin{array}{l}\mu \mathrm{mol}(\mu \mathrm{mol} \\
\text { bacteria } \mathrm{d})^{-1}\end{array}$ & $0.1-80$ & 8.43 & 6.00 & 3.34 & 0.56 \\
\hline$K_{\mathrm{S}, \mathrm{SRC}}$ & $\mu \mathrm{mol} \mathrm{L}^{-1}$ & $23-400$ & 392 & 260 & 109.1 & 0.42 \\
\hline$K_{\mathrm{OC}, \mathrm{GLP}}$ & $\mathrm{L} \mathrm{kg}^{-1}$ & $211-1689$ & 878 & 901 & 84.6 & 0.09 \\
\hline$v_{\text {max,AMPA }}$ & $\begin{array}{l}\mu \mathrm{mol}(\mu \mathrm{mol} \\
\text { bacteria } \mathrm{d})^{-1}\end{array}$ & $0.5-30$ & 25.7 & 19,2 & 6.46 & 0.34 \\
\hline$K_{\mathrm{S}, \mathrm{AMPA}}$ & $\mu \mathrm{mol} \mathrm{L} \mathrm{L}^{-1}$ & $400-1500$ & 1364 & 966 & 327 & 0.34 \\
\hline$K_{\mathrm{I}}$ & $\mu \mathrm{mol} \mathrm{L} \mathrm{L}^{-1}$ & $1-879$ & 712 & 582 & 207 & 0.36 \\
\hline$X(0)$ & $\mu \mathrm{mol} \mathrm{L}^{-1}$ & $0.01-1$ & 0.0018 & 0.006 & 0.006 & 1.0 \\
\hline
\end{tabular}

Table S9: Correlation matrix obtained by the parameter fitting in the DREAM parameter optimization for alternative hypothesis 1: competitive inhibition.

\begin{tabular}{|c|c|c|c|c|c|c|c|}
\hline & $v_{\text {max,SRC }}^{\mathrm{GLP}}$ & $K_{\mathrm{S}, \mathrm{SRC}}$ & $K_{\mathrm{OC}, \mathrm{GLP}}$ & $v_{\text {max,AMPA }}$ & $K_{\mathrm{S}, \mathrm{AMPA}}$ & $K_{\mathrm{I}}$ & $X(0)$ \\
\hline$v_{\max , \mathrm{SRC}}$ & 1.00 & & & & & & \\
\hline$K_{\mathrm{S}, \mathrm{SRC}}$ & 0.72 & 1.00 & & & & & \\
\hline$K_{\mathrm{OC}, \mathrm{GLP}}$ & 0.24 & 0.10 & 1.00 & & & & \\
\hline$v_{\text {max,AMPA }}$ & 0.10 & 0.09 & 0.17 & 1.00 & & & \\
\hline$K_{\mathrm{S}, \mathrm{AMPA}}$ & 0.05 & 0.06 & -0.04 & 0.92 & 1.00 & & \\
\hline$K_{\mathrm{I}}$ & -0.38 & 0.09 & -0.07 & -0.08 & 0.03 & 1.00 & \\
\hline$X(0)$ & -0.56 & -0.31 & -0.29 & -0.06 & 0.00 & 0.25 & 1.00 \\
\hline
\end{tabular}

The simplified model for $\mathrm{P}_{\mathrm{i}}$ inhibition can capture the observations to a degree comparable to the model assuming nitrogen to drive the degradation of glyphosate and the shift in transformation pathways. The coefficients of variation of the $P_{i}$ inhibition model are generally higher than for the nitrogen model, whereas the parameter correlation is slightly lower. Based on the lack of $\mathrm{P}_{\mathrm{i}}$ measurements, and the simplifying assumptions related to the dynamics of $\mathrm{P}_{\mathrm{i}}$ in the experimental 
system, makes it difficult to assess which process is the decisive process, however, the measurements of ${ }^{15} \mathrm{~N}$ incorporated into microbial mass clearly favors the "nitrogen model".

S6.2 Alternative hypothesis $\mathbf{2}$ is addressed in the model by including a process for the productive biodegradation of AMPA leading to formation of $\mathrm{CO}_{2}$ and biomass. Consequently, the following term is added (as a removal process) to Equation (S39) (similar to Equation (12)):

$\frac{\mathrm{d} n_{\mathrm{M}, \mathrm{AMPA}-\mathrm{OX}}}{\mathrm{d} t}=v_{\text {max,AMPA-OX }} \frac{a_{\mathrm{D}}^{\mathrm{AMPA}}}{a_{\mathrm{D}}^{\mathrm{AMPA}}+K_{\mathrm{S}, \mathrm{AMPA}-\mathrm{OX}}} X$

379

380 Similarly, Equations (13) and (16) are changed:

$$
\begin{aligned}
& \frac{\mathrm{d} X}{\mathrm{~d} t}=Y_{\mathrm{SRC}} \times \frac{\mathrm{d} n_{\mathrm{M}, \mathrm{SRC}}}{\mathrm{d} t}+ Y_{\mathrm{AMPA}} \times \frac{\mathrm{d} n_{\mathrm{M}, \mathrm{AMPA}}}{\mathrm{d} t}+Y_{\mathrm{AMPA}-\mathrm{OX}} \times \frac{\mathrm{d} n_{\mathrm{M}, \mathrm{AMPA}-\mathrm{OX}}}{\mathrm{d} t}-b \times X \\
& \frac{\mathrm{d} n_{C O_{2}}}{\mathrm{~d} t}=\left(1-Y_{\mathrm{SRC}}^{C}\right) \frac{\mathrm{d} n_{\mathrm{M}, \mathrm{SRC}}}{\mathrm{d} t} n_{\mathrm{C}, \mathrm{SRC}}+\left(1-Y_{\mathrm{AMPA}}^{C}\right) \frac{\mathrm{d} n_{\mathrm{M}, \mathrm{AMPA}}}{\mathrm{d} t} n_{\mathrm{C}, \mathrm{AMPA}} \\
&+\left(1-Y_{\mathrm{AMPA}-\mathrm{OX}}^{C}\right) \frac{\mathrm{d} n_{\mathrm{M}, \mathrm{AMPA}-\mathrm{OX}}}{\mathrm{d} t} n_{\mathrm{C}, \mathrm{AMPA}-\mathrm{OX}}+k_{\mathrm{m}} X_{\text {necro }} n_{\mathrm{C}, \text { cell }}
\end{aligned}
$$

382 Where $v_{\max }\left[\mu \mathrm{mol}(\mu \mathrm{mol} \text { bacteria } \mathrm{d})^{-1}\right]$ is the maximum transformation rate and $K_{\mathrm{S}}\left[\mu \mathrm{mol} \mathrm{L} \mathrm{L}^{-1}\right]$ is the 383 half-saturation constant, $Y_{\text {AMPA-Ox }}$ is microbial growth yield (moles of $C$ in bacteria per moles of $C$ 384 in substrate, or $\mathrm{g} \mathrm{C} \mathrm{/} \mathrm{g} \mathrm{C}$ ) and $Y_{\mathrm{AMPA}-\mathrm{OX}}$ is the microbial growth yield in $\mu$ mol bacteria ( $\mu \mathrm{mol}$ 385 substrate) ${ }^{-1}$. The subscript AMPA-OX denotes the oxidation of AMPA to $\mathrm{CO}_{2} . n_{\mathrm{C}, \mathrm{AMPA}-\mathrm{OX}}$ is the 386 number of carbon atoms in AMPA (equal to 1). 
Table S10: Range of prior uniform distributions used in the DREAM parameter optimization, and 389 mean, standard deviation and coefficient of variation of the resulting posterior distributions for 390 alternative hypothesis 2: AMPA is biodegradable while the sarcosine pathway is competitively 391 inhibited by ortho-phosphate.

\begin{tabular}{|c|c|c|c|c|c|c|}
\hline Parameter & Unit & $\begin{array}{l}\text { Range of prior } \\
\text { distribution }\end{array}$ & Optimum & $\begin{array}{l}\text { Mean, } \\
\mu\end{array}$ & $\begin{array}{l}\text { Standard } \\
\text { deviation, } \sigma\end{array}$ & $\begin{array}{l}\text { Coefficient of } \\
\text { variation } \sigma / \mu\end{array}$ \\
\hline \multirow{2}{*}{$v_{\max , \mathrm{SRC}}$} & $\mu \mathrm{mol}(\mu \mathrm{mol}$ & $0.1-80$ & & & & \\
\hline & bacteria $d)^{-1}$ & & 9.55 & 5.26 & 3.77 & 0.72 \\
\hline$K_{\mathrm{S}, \mathrm{SRC}}$ & $\mu \mathrm{mol} \mathrm{L} \mathrm{L}^{-1}$ & $23-400$ & 395 & 249 & 104 & 0.42 \\
\hline$K_{\mathrm{OC}, \mathrm{GLP}}$ & $\mathrm{L} \mathrm{kg}^{-1}$ & $211-1689$ & 893 & 895 & 80.3 & 0.09 \\
\hline \multirow{2}{*}{$v_{\text {max,AMPA }}$} & $\mu \mathrm{mol}(\mu \mathrm{mol}$ & $0.5-30$ & & & & \\
\hline & bacteria $d)^{-1}$ & & 27.6 & 21.2 & 5.98 & 0.28 \\
\hline$K_{\mathrm{S}, \mathrm{AMPA}}$ & $\mu \mathrm{mol} \mathrm{L} \mathrm{L}^{-1}$ & $400-1500$ & 1393 & 998 & 307 & 0.31 \\
\hline$K_{\mathrm{I}}$ & $\mu \mathrm{mol} \mathrm{L} \mathrm{L}^{-1}$ & $1-879$ & 550 & 529 & 239 & 0.45 \\
\hline$X(0)$ & $\mu \mathrm{mol} \mathrm{L}{ }^{-1}$ & $0.01-1$ & 0.0012 & 0.009 & 0.01 & 1.09 \\
\hline \multirow[t]{2}{*}{$v_{\text {max,AMPA-OX }}$} & $\mu \mathrm{mol}(\mu \mathrm{mol}$ & $0.001-100$ & & & & \\
\hline & bacteria $\mathrm{d})^{-1}$ & & 0.15 & 0.774 & 0.70 & 0.91 \\
\hline$K_{\mathrm{S}, \mathrm{AMPA}-\mathrm{OX}}$ & $\mu \mathrm{mol} \mathrm{L} \mathrm{L}^{-1}$ & $0.01-1000$ & 618 & 613 & 257 & 0.42 \\
\hline
\end{tabular}


Table S11: Correlation matrix obtained by the parameter fitting in the DREAM parameter optimization for alternative hypothesis 2: AMPA is biodegradable.

\begin{tabular}{|c|c|c|c|c|c|c|c|c|c|}
\hline & $v_{\text {max }, \mathrm{SRC}}^{\mathrm{GLP}}$ & $K_{\mathrm{S}, \mathrm{SRC}}$ & $K_{\mathrm{OC}, \mathrm{GLP}}$ & $v_{\text {max,AMPA }}$ & $K_{\mathrm{S}, \mathrm{AMPA}}$ & $K_{\mathrm{I}}$ & $X(0)$ & $v_{\text {max,AMPA-OX }}$ & $K_{\mathrm{S}, \mathrm{AMPA}-\mathrm{OX}}$ \\
\hline$v_{\max , \mathrm{SRC}}$ & 1.00 & & & & & & & & \\
\hline$K_{\mathrm{S}, \mathrm{SRC}}$ & 0.63 & 1.00 & & & & & & & \\
\hline$K_{\mathrm{OC}, \mathrm{GLP}}$ & 0.22 & 0.11 & 1.00 & & & & & & \\
\hline$v_{\max , \mathrm{AMPA}}$ & -0.05 & -0.05 & 0.12 & 1.00 & & & & & \\
\hline$K_{\mathrm{S}, \mathrm{AMPA}}$ & -0.02 & -0.06 & -0.11 & 0.85 & 1.00 & & & & \\
\hline$K_{\mathrm{I}}$ & -0.39 & 0.12 & -0.12 & 0.04 & 0.19 & 1.00 & & & \\
\hline$X(0)$ & -0.45 & -0.12 & 0.02 & -0.03 & -0.14 & 0.14 & 1.00 & & \\
\hline$v_{\text {max,AMPA-OX }}$ & -0.02 & 0.03 & 0.00 & 0.03 & -0.16 & -0.16 & 0.48 & 1.00 & \\
\hline$K_{\mathrm{S}, \mathrm{AMPA}-\mathrm{OX}}$ & -0.04 & -0.02 & -0.04 & 0.09 & 0.06 & 0.06 & 0.12 & 0.51 & 1.00 \\
\hline
\end{tabular}

397 The alternative hypothesis 2 introduces two new fit parameters related to the mineralization of 398 AMPA. The RMSE of the optimum parameter set was $2.1 \mu \mathrm{mol}$, which is similar to alternative 399 hypothesis 1. The parameter correlation is slightly lower, however; this is partly explained by the 400 poorer identifiability of the parameters, which can be seen from the coefficients of variation, which 401 are generally higher than for both the nitrogen model and the $P_{i}$ inhibition model. The effect 402 imparted on the system by this extra process can be analyzed by using the $v_{\max } / K_{\mathrm{S}}$ ratio as an 403 indicator. It is $0.024 \mathrm{~L}(\mu \mathrm{mol} \text { bacteria } \mathrm{d})^{-1}$ and $0.020 \mathrm{~L}(\mu \mathrm{mol} \text { bacteria } \mathrm{d})^{-1}$ for the sarcosine pathway 404 and the formation AMPA and oxidation of glyoxylate, respectively. For the oxidation of AMPA, it is $4050.0002 \mathrm{~L}(\mu \mathrm{mol} \text { bacteria } \mathrm{d})^{-1}$, which shows, that the effect on the model performance is negligible. 406 This indicates that AMPA is not further degraded, and that the assumption of AMPA as an 407 accumulating metabolite in the experimental system is an acceptable assumption. 
411 Table S12: Mass balance of ${ }^{13} \mathrm{C}$ carbon measured in $\mathrm{CO}_{2}$, glyphosate, AMPA and NER. The unit is $412 \mu \mathrm{mol}{ }^{13} \mathrm{C}$ and the measurements have been corrected by the recovery ${ }^{4}$.

\begin{tabular}{r|rrrr}
\hline \multicolumn{1}{l}{ Time (days) } & $\mathrm{CO}_{2}$ & Glyphosate & AMPA & NER \\
\hline 0 & 0.0 & 73.4 & 0.1 & 4.5 \\
5 & 0.8 & 54.1 & 0.8 & 22.3 \\
10 & 2.5 & 47.0 & 0.8 & 27.7 \\
20 & 12.4 & 34.0 & 4.6 & 27.0 \\
40 & 30.6 & 6.9 & 16.8 & 23.7 \\
80 & 39.7 & 3.5 & 18.4 & 16.3 \\
\hline
\end{tabular}

414 Table S13: Mass balance of ${ }^{15} \mathrm{~N}$ carbon measured in glyphosate, AMPA and NER. The unit is $\mu \mathrm{mol}$ $415{ }^{15} \mathrm{~N}$ and the measurements have been corrected by the recovery ${ }^{4}$.

\begin{tabular}{r|rrr}
\hline Time (days) & Glyphosate & AMPA & NER \\
\hline 0 & 24.5 & 0.25 & 1.3 \\
5 & 19.4 & 0.86 & 5.7 \\
10 & 16.9 & 1.2 & 7.9 \\
20 & 12.6 & 4.9 & 8.6 \\
40 & 2.2 & 16.1 & 7.7 \\
80 & 1.2 & 18.7 & 6.2 \\
\hline
\end{tabular}

S8. Calculation of biomass and $\mathrm{CO} 2$ formation with the modified MTB carbon balance

418 The formation of biomass can also be estimated using the growth yields and the carbon balance of 419 the modified MTB approach. ${ }^{16}$ The equations are presented in the manuscript (Equations (5-8)).

$421 Y_{\text {AMPA }}$ of the AMPA pathway is $0.19 \mathrm{~mol} \mathrm{C}(\mathrm{mol} \mathrm{C})^{-1}$ (Table 1$)$, thus $n_{\mathrm{ox}}$ is equal to

$$
n_{o x}=1-0.19-\frac{1}{3}=0.48 \frac{\mathrm{mol} \mathrm{C}}{\mathrm{mol} \mathrm{C}}
$$

422 With $18.4 \mu \mathrm{mol}$ AMPA formed (Table S8), at least $18.4 \mu \mathrm{mol}$ glyphosate, or $55.2 \mu \mathrm{mol} \mathrm{C}$, were 423 degraded via the AMPA pathway. It then follows that the biomass $X$ and $\mathrm{CO}_{2}$ formed are 


$$
\begin{aligned}
& X=Y_{\mathrm{AMPA}}^{\mathrm{C}} \times C_{\mathrm{GLP}}=0.19 \times 55.2=10.5 \mu \mathrm{mol} \quad{ }^{13} \mathrm{C} \\
& \mathrm{CO}_{2}=n_{\mathrm{ox}} \times C_{\mathrm{GLP}}=0.48 \times 55.2=26.5 \mu \mathrm{mol} \quad{ }^{13} \mathrm{C}
\end{aligned}
$$

424

425

426

427

428

\section{S8.2 Sarcosine pathway}

Of the initial $26 \mu \mathrm{mol}$ GLP, $1.2 \mu \mathrm{mol}$ remain, $18.4 \mu \mathrm{mol}$ were degraded via the AMPA pathway, thus $6.4 \mu \mathrm{mol}$ GLP or $19.2 \mu \mathrm{mol} \mathrm{C}$ are metabolized via the sarcosine pathway (Table S8). With a yield of $0.46 \mathrm{~mol} \mathrm{C} / \mathrm{mol} \mathrm{C}$, the biomass $X$ and $\mathrm{CO}_{2}$ formed are

$$
\begin{aligned}
& X=Y_{\mathrm{GLP}}^{\mathrm{C}} \times C_{\mathrm{GLP}}=0.46 \times 19.2=8.8 \mu \mathrm{mol} \quad{ }^{13} \mathrm{C} \\
& \mathrm{CO}_{2}=\left(1-Y_{\mathrm{GLP}}^{\mathrm{C}}\right) \times C_{\mathrm{GLP}}=0.54 \times 19.2=10.3 \mu \mathrm{mol} \quad{ }^{13} \mathrm{C}
\end{aligned}
$$

429 The calculated total biomass formed is $19.3 \mu \mathrm{mol}{ }^{13} \mathrm{C}$. Conversely, the total amount of formed $\mathrm{CO}_{2}$ 430 is calculated to be $36.8 \mu \mathrm{mol}{ }^{13} \mathrm{C}$. The calculated $\mathrm{CO}_{2}$ produced is lower than $\mathrm{CO}_{2}$ actually 431 measured. Disregarding microbial growth (growth yields equal to 0 ) the maximum amount of $\mathrm{CO}_{2}$ 432 that can be formed is $56 \mu \mathrm{mol}$. The difference between this and the measured ${ }^{13} \mathrm{CO}_{2}$ is equal to $43316.3 \mu \mathrm{mol}{ }^{13} \mathrm{C}$. This amount is likely to be representative of the biomass formed. The reason that 434 the calculated $X\left(19.3 \mu \mathrm{mol}{ }^{13} \mathrm{C}\right)$ is higher than this amount and the calculated $\mathrm{CO}_{2}$ is lower than 435 measured $\mathrm{CO}_{2}$ presumably caused by turnover of biomass $X$ in the microbial food web and some 436 glyphosate sequestered in the sediment (NER). Alternatively, the difference may reflect the 437 expense of energy that needs to be spent for anabolism from other $C$ sources. However, if we 438 consider that during this turnover, up to $50 \%$ of the biomass is forming $\mathrm{CO}_{2},{ }^{16}$ the lower range of 439 bioNER is $9.65 \mu \mathrm{mol}{ }^{13} \mathrm{C}$ and the upper range for $\mathrm{CO}_{2}$ is $46 \mu \mathrm{mol}{ }^{13} \mathrm{C}$ covering the measured 440 values. 


\section{References}

(1) Flamholz, A.; Noor, E.; Bar-Even, A.; Milo, R. eQuilibrator - The Biochemical Thermodynamics Calculator. Nucleic Acids Res. 2012, 40 (D1), 770-775.

(2) Caspi, R.; Billington, R.; Fulcher, C. A.; Keseler, I. M.; Kothari, A.; Krummenacker, M.; Latendresse, M.; Midford, P. E.; Ong, Q.; Ong, W. K.; et al. The MetaCyc Database of Metabolic Pathways and Enzymes. Nucleic Acids Res. 2018, 46 (D1), D633-D639.

(3) Alberty, R. A. Thermodynamics of Biochemical Reactions; Wiley-Interscience, John Wiley \& Sons: Hoboken, New Jersey., 2003; Vol. 357.

(4) Wang, S.; Seiwert, B.; Kästner, M.; Miltner, A.; Schäffer, A.; Reemtsma, T.; Yang, Q.; Nowak, K. M. (Bio)Degradation of Glyphosate in Water-Sediment Microcosms - A Stable Isotope Co-Labeling Approach. Water Res. 2016, 99, 91-100.

(5) Hove-Jensen, B.; Zechel, D. L.; Jochimsen, B. Utilization of Glyphosate as Phosphate Source: Biochemistry and Genetics of Bacterial Carbon-Phosphorus Lyase. Microbiol. Mol. Biol. Rev. 2014, 78 (1), 176-197.

(6) la Cecilia, D.; Maggi, F. Analysis of Glyphosate Degradation in a Soil Microcosm. Environ. Pollut. 2018, 233, 201-207.

(7) Nowak, K. M.; Miltner, A.; Gehre, M.; Schäffer, A.; Kastner, M. Formation and Fate of Bound Residues from Microbial Biomass during 2, 4-D Degradation in Soil. Environ. Sci. Technol. 2011, 45 (3), 999-1006.

(8) Nowak, K. M.; Girardi, C.; Miltner, A.; Gehre, M.; Schäffer, A.; Kästner, M. Contribution of Microorganisms to Non-Extractable Residue Formation during Biodegradation of Ibuprofen in Soil. Sci. Total Environ. 2013, 445-446, 377-384.

(9) Poßberg, C.; Schmidt, B.; Nowak, K.; Telscher, M.; Lagojda, A.; Schäffer, A. Quantitative Identification of Biogenic Nonextractable Pesticide Residues in Soil by 14C-Analysis. Environ. Sci. Technol. 2016, 50 (12), 6415-6422.

(10) Wang, S.; Miltner, A.; Nowak, K. M. Identification of Degradation Routes of Metamitron in Soil Microcosms Using 13C-Isotope Labeling. Environ. Pollut. 2017, 220, 927-935.

(11) Wang, S.; Miltner, A.; Kästner, M.; Schäffer, A.; Nowak, K. M. Transformation of Metamitron in Water-Sediment Systems: Detailed Insight into the Biodegradation Processes. Sci. Total 
Environ. 2017, 578, 100-108.

(12) Kästner, M.; Trapp, S.; Schäffer, A. Consultancy Services to Support ECHA in Improving the Interpretation of Non-Extractable Residues (NER) in Degradation Assessment. Discussion Paper - Final Report. Edited by the European Chemical Agency ECHA (June 2018), available at www.echa.europa.eu/publications/technical-scientific-reports.

(13) Madigan, M. T., Martinko, J. M., Bender, K. S., Buckley, D. H., \& Stahl, D. A. Brock Biology of Microorganisms, 14th ed.; Pearson Inc.: Boston, USA, 2014.

(14) Kozlowski, L. P. Proteome-PI: Proteome Isoelectric Point Database. Nucleic Acids Res. 2017, 45 (D1), D1112-D1116.

(15) Christensen, D. R.; McCarty, P. L. Multi-Process Biological Treatment Model. J. (Water Pollut. Control Fed). 1975, 47 (11), 2652-2664.

(16) Trapp, S.; Brock, A. L.; Nowak, K.; Kästner, M. Prediction of the Formation of Biogenic Nonextractable Residues during Degradation of Environmental Chemicals from Biomass Yields. Environ. Sci. Technol. 2018, 52 (2), 663-672.

(17) Kindler, R.; Miltner, A.; Thullner, M.; Richnow, H. H.; Kästner, M. Fate of Bacterial Biomass Derived Fatty Acids in Soil and Their Contribution to Soil Organic Matter. Org. Geochem. 2009, 40 (1), 29-37.

(18) Miltner, A.; Bombach, P.; Schmidt-Brücken, B.; Kästner, M. SOM Genesis: Microbial Biomass as a Significant Source. Biogeochemistry 2012, 111 (1-3), 41-55.

(19) OECD. Test No. 308: Aerobic and Anaerobic Transformation in Aquatic Sediment Systems; Paris, 2002.

(20) Shrestha, P.; Junker, T.; Fenner, K.; Hahn, S.; Honti, M.; Bakkour, R.; Diaz, C.; Hennecke, D. Simulation Studies to Explore Biodegradation in Water-Sediment Systems: From OECD 308 to OECD 309. Environ. Sci. Technol. 2016, 50 (13), 6856-6864.

(21) FOCUS. Guidance Document on Estimating Persistence and Degradation Kinetics from Environmental Fate Studies on Pesticides in EU Registration. Report of the FOCUS Work Group on Degradation Kinetics, EC Sanco/10058/2005. 2006, pp 1-434.

(22) Final addendum to the Renewal Assesment Report. Risk Assessment Provided by the Rapporteur Member State Germany and Co-Rapporteur Member State Slovakia for the 
Active Substance Glyphosate According to the Procedure for the Renewal of the Inclusion of a Second Group of Active Substances in Annex I to Council Direvtive 91/414/EEC laid down in the Commision Regulation (EU) No. 1141/2010. 2015.

(23) Honti, M.; Fenner, K. Deriving Persistence Indicators from Regulatory Water-Sediment Studies - Opportunities and Limitations in OECD 308 Data. Environ. Sci. Technol. 2015, 49 (10), 5879-5886.

(24) Millington, R. J.; Quirk, J. P. Permeability of Porous Solids. Trans. Faraday Soc. 1961, 57, 1200-1207.

(25) Helbling, D. E.; Johnson, D. R.; Lee, T. K.; Scheidegger, A.; Fenner, K. A Framework for Establishing Predictive Relationships between Specific Bacterial 16S RRNA Sequence Abundances and Biotransformation Rates. Water Res. 2015, 70, 471-484.

(26) Kästner, M.; Nowak, K. M.; Miltner, A.; Trapp, S.; Schäffer, A. Classification and Modelling of Nonextractable Residue (NER) Formation of Xenobiotics in Soil - A Synthesis. Crit. Rev. Environ. Sci. Technol. 2014, 44 (19), 2107-2171.

(27) Rein, A.; Adam, I. K. U.; Miltner, A.; Brumme, K.; Kästner, M.; Trapp, S. Impact of Bacterial Activity on Turnover of Insoluble Hydrophobic Substrates (Phenanthrene and Pyrene )Model Simulations for Prediction of Bioremediation Success. J. Hazard. Mater. 2016, 306, $105-114$.

(28) Vrugt, J. A. Markov Chain Monte Carlo Simulation Using the DREAM Software Package: Theory, Concepts, and MATLAB Implementation. Environ. Model. Softw. 2016, 75, $273-$ 316.

(29) Sviridov, A. V.; Shushkova, T. V.; Zelenkova, N. F.; Vinokurova, N. G.; Morgunov, I. G.; Ermakova, I. T.; Leontievsky, A. A. Distribution of Glyphosate and Methylphosphonate Catabolism Systems in Soil Bacteria Ochrobactrum Anthropi and Achromobacter Sp. Appl. Microbiol. Biotechnol. 2012, 93 (2), 787-796. 